\title{
STORM-TIDE ELEVATIONS PRODUCED BY HURRICANE ANDREW ALONG THE LOUISIANA COAST, AUGUST 25-27, 1992
}

\section{U.S. GEOLOGICAL SURVEY Open-File Report 94-371}

Prepared in cooperation with the FEDERAL EMERGENCY MANAGEMENT AGENCY 


\section{STORM-TIDE ELEVATIONS PRODUCED BY HURRICANE ANDREW ALONG THE LOUISIANA COAST, AUGUST 25-27, 1992}

By John K. Lovelace

U.S. GEOLOGICAL SURVEY

Open-File Report 94-371

Prepared in cooperation with the:

FEDERAL EMERGENCY MANAGEMENT AGENCY

Baton Rouge, Louisiana 


\section{U.S. DEPARTMENT OF THE INTERIOR BRUCE BABBITT, Secretary \\ U.S. GEOLOGICAL SURVEY \\ GORDON P. EATON, Director}

For additional information write to:

District Chief

U.S. Geological Survey

3535 S. Sherwood Forest Blvd.

Suite 120

Baton Rouge, LA 70816
Copies of this report can be purchased from:

U.S. Geological Survey

Earth Science Information Center

Open-File Reports Section

Box 25286, MS 517

Denver Federal Center

Denver, CO 80225 


\section{CONTENTS}

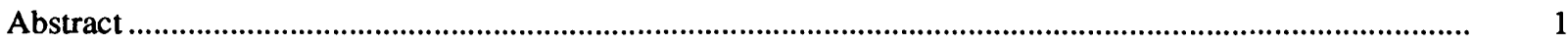

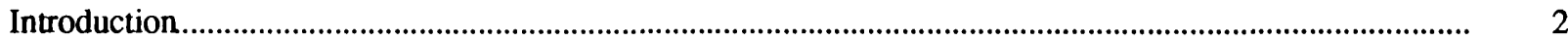

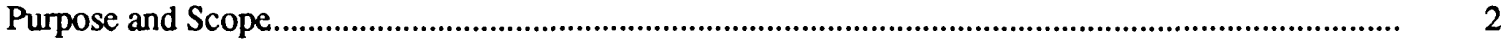

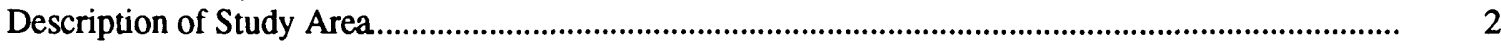

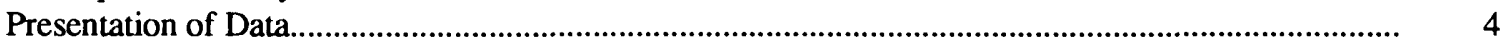

Acknowledgments.................................................................................................................................. 4

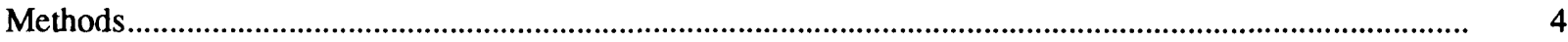

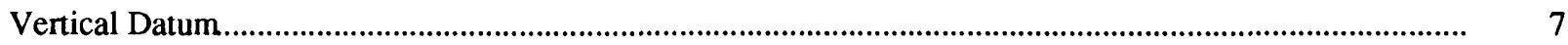

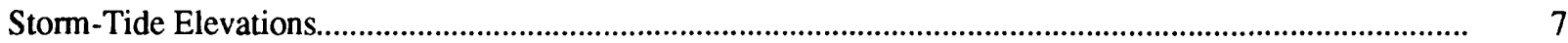

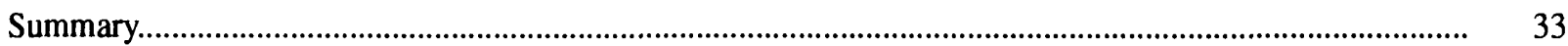

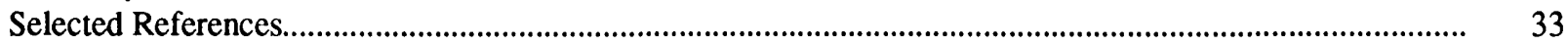

\section{PLATES}

[Plates are in pocket]

1-12. Maps showing high-water marks, continuous gaging stations, and water-surface elevations

of storm-tide inundation caused by Hurricane Andrew, August 25-27, 1992:

1. Lake Charles, Louisiana, Texas quadrangle

2. Crowley, Louisiana quadrangle

3. Ponchatoula, Louisiana quadrangle

4. Gulfport, Mississippi, Louisiana quadrangle

5. Port Arthur, Texas, Louisiana quadrangle

6. White Lake, Louisiana quadrangle

7. Morgan City, Louisiana quadrangle

8. New Orleans, Louisiana quadrangle

9. Black Bay, Louisiana quadrangle

10. Atchafalaya Bay, Louisiana quadrangle

11. Terrebonne Bay, Louisiana quadrangle

12. Mississippi River Delta, Louisiana quadrangle

\section{FIGURES}

1-3. Maps showing:

1. The path of Hurricane Andrew, extent of tropical storm- and hurricane-force winds, and storm-tide elevations at selected sites in Louisiana.

2. Locations and boundaries of quadrangles for which storm-tide elevations are shown ............... 5

3. Location of selected gaging stations from which time-series data are presented ............................. 6

4-10. Graphs showing:

4. Estimated elevation and specific conductance at gaging station 1, north California Bay near Pointe-a-la-Hache, Louisiana

5. Estimated elevation and specific conductance at gaging station 2, northeast Bay Gardene near Pointe-a-la-Hache, Louisiana.

6. Elevation and stream velocity at gaging station 3, Wax Lake Outlet at

Calumet, Louisiana.

7. Elevation and stream velocity at gaging station 4, Bayou Grand Caillou at Dulac, Louisiana.

8. Estimated elevation and specific conductance at gaging station 5, Black Bay near

Snake Island and Pointe-a-la-Hache, Louisiana.

9. Estimated elevation and specific conductance at gaging station 6, California Bay near Sunrise Point, northeast of Nairn, Louisiana.

10. Gage height and specific conductance at gaging station 7, unnamed lake tributary to Lake Boudreaux, southwest of Chauvin, Louisiana. 
11-27. Graphs showing:

11. Elevation and stream velocity at gaging station 8, Mermentau River at

Mermentau, Louisiana.

12. Elevation and stream velocity at gaging station 9, Vermilion River at Perry, Louisiana............ 17

13. Elevation and stream velocity at gaging station 10, Bayou Teche near Franklin, Louisiana.

14. Elevation at gaging station 11, Lower Atchafalaya River below Sweet Bay Lake, near Morgan City, Louisiana.

5. Elevation at gaging station 12, Lower Atchafalaya River at Morgan City, Louisiana.

16. Elevation and specific conductance at gaging station 13, Houma Navigation Canal at Dulac, Louisiana.

17. Elevation and specific conductance at gaging station 14, Lareussite Canal near Naomi, Louisiana.

18. Elevation and stream velocity at gaging station 15, Bayou Lacassine near Lake Arthur, Louisiana.

19. Elevation and specific conductance at gaging station 16, Grand Bayou Tributary, west of Galliano, Louisiana.

20. Elevation and specific conductance at gaging station 17, The Rigolets near Slidell, Louisiana

21. Elevation and specific conductance at gaging station 18, Barataria Pass, east of Grand Isle, Louisiana .

22. Elevation and specific conductance at gaging station 19, Barataria Bay, north of Grand Isle, Louisiana.

23. Elevation and specific conductance at gaging station 20, Tennessee Canal near Cut Off, Louisiana.

24. Elevation and specific conductance at gaging station 21, Little Lake near Cut Off, Louisiana.

25. Elevation and specific conductance at gaging station 22, Vermilion Bay near Cypremort Point, Louisiana.

26. Elevation and specific conductance at gaging station 23 , north Calcasieu Lake near Hackberry, Louisiana.

27. Elevation and specific conductance at gaging station 24, East Fork Tributary near Cameron, Louisiana.

\section{TABLES}

1. Location, description, and elevation of high-water marks along the Louisiana coast.

2. Location, description, and elevation for peak storm-tide measurements at selected continuous gaging stations along the Louisiana coast.

\section{CONVERSION FACTORS AND VERTICAL DATUM}

\begin{tabular}{rll}
\hline Multiply & By & To obtain \\
\hline foot $(\mathrm{ft})$ & 0.3048 & meter \\
foot per second $(\mathrm{ft} / \mathrm{s})$ & 0.3048 & meter per second \\
mile $(\mathrm{mi})$ & 1.609 & kilometer \\
mile per hour $(\mathrm{mi} / \mathrm{h})$ & 1.609 & kilometer per hour \\
\hline
\end{tabular}

Temperature in degrees Celsius $\left({ }^{\circ} \mathrm{C}\right)$ can be converted to degrees Fahrenheit $\left({ }^{\circ} \mathrm{F}\right)$ as follows: ${ }^{\circ} \mathrm{F}=1.8\left({ }^{\circ} \mathrm{C}\right)+32$.

Sea level: In this report, "sea level" refers to the National Geodetic Vertical Datum of 1929 (NGVD of 1929)_-a geodetic datum derived from a general adjustment of the first-order level nets of both the United States and Canada, formerly called Sea Level Datum of 1929. 


\title{
Storm-Tide Elevations Produced by Hurricane Andrew along the Louisiana Coast, August 25-27, 1992
}

\author{
By John K. Lovelace
}

\begin{abstract}
Hurricane Andrew made landfall at Point Chevreuil, Louisiana, on August 26, 1992, at approximately 3:30 a.m. The hurricane produced a storm tide that affected much of the Louisiana coastline, including many coastal waterways and lakes hydraulically connected to the coast.

Data were collected on high-water marks, resulting from the storm tide, at 69 sites in coastal areas of southeastern and south-central Louisiana, in addition to the data recorded at 76 gaging stations located near or on the coast. High-water-mark data and gaging-station data are presented on a series of 12 quadrangle maps and in tabular form. Line graphs of time-series data from 24 gaging stations also are presented.

The counter-clock-wise motion of the hurricane winds pushed water landward in areas east of landfall, producing a positive storm tide along the Louisiana coast from the Mississippi State line to landfall. West of landfall, the winds pushed the water seaward, producing a negative storm tide in areas along the Louisiana coast to the Texas State line. The storm tide peaked at 9.3 feet above sea level near Cocodrie, La., and at 8.2 feet above sea level near landfall. Other approximate storm-tide elevations (in feet above sea level) along the Louisiana coast were as follows: Lake Pontchartrain, 4; Breton Sound, 5; Barataria Bay, 4; Grand Isle, 4; Terrebonne Bay, 9; Atchafalaya Bay, 8; East Cote Blanche Bay, 8; Vermilion Bay, -3; and Calcasieu Pass, -1 .
\end{abstract}




\section{INTRODUCTION}

Hurricane Andrew made landfall at Point Chevreuil, La., on August 26, 1992, at approximately 3:30 in the morning (Rappaport, 1992). The hurricane struck the sparsely populated coastal area with $115 \mathrm{mi} / \mathrm{h}$ sustained winds and hurricane-force winds (greater than or equal to $73 \mathrm{mi} / \mathrm{h}$ ) extending 70 mi outward from the eye (National Oceanic and Atmospheric Administration, 1992). The path of Andrew through Louisiana and the areal extent of hurricane- and tropical storm-force winds are shown in figure 1. (Tropical storm-force winds have wind speeds greater than or equal to $39 \mathrm{mi} / \mathrm{h}$ but less than $73 \mathrm{mi} / \mathrm{h}$.) The U.S. Geological Survey (USGS), in cooperation with the Federal Emergency Management Agency (FEMA), collected elevation data in Louisiana on the storm tide produced by Hurricane Andrew.

\section{Purpose and Scope}

This report presents data collected on high-water marks at 69 sites and stage data recorded at 24 gaging stations located on or near the Louisiana coast. Eight of these gages are maintained by the USGS and 16 of the gages are maintained jointly by the USGS and the Louisiana Department of Natural Resources (DNR). In addition, this report presents peak-stage data compiled and provided by the U.S. Army Corps of Engineers (COE) for 52 gaging stations located on or near the coast. Data presented in this study were collected in coastal parishes in Louisiana and the parishes surrounding Lake Pontchartrain. The data presented may be useful for flood-insurance purposes, storm-tide modeling, and planning future development in areas impacted by Hurricane Andrew's storm tide. All data presented in this report are on file at the USGS office in Baton Rouge, Louisiana.

\section{Description of Study Area}

Along the coast of south-central Louisiana where Hurricane Andrew made landfall, the shallow seafloor slopes gently up to meet the low marshlands that characterize coastal areas of southern Louisiana. These marshes extend inland for distances ranging from 10 to $30 \mathrm{mi}$. Barrier islands exist along much of the coasts of Terrebonne and Lafourche Parishes (fig. 1). In the past, it was thought that these islands may provide some protection from the wave action of storms. Today, however, these islands are generally low, thin, and broken from previous storms and do little to buffer the effects of hurricanes. It was also thought that the marshes may reduce the inland movement of a storm tide. However, the numerous canals and bayous throughout the coastal marshes provide unrestricted access for the movement of high water.

Most of the population residing close to the coast in south-central Louisiana live along a few naturally occurring levees or have built private levees to protect their property. Many homes and the numerous fishing camps are built several feet off of the ground on pilings for protection against flooding. In areas farther from the coast, hurricane-protection levees have been constructed to protect larger populations. 
A R K A N S A S

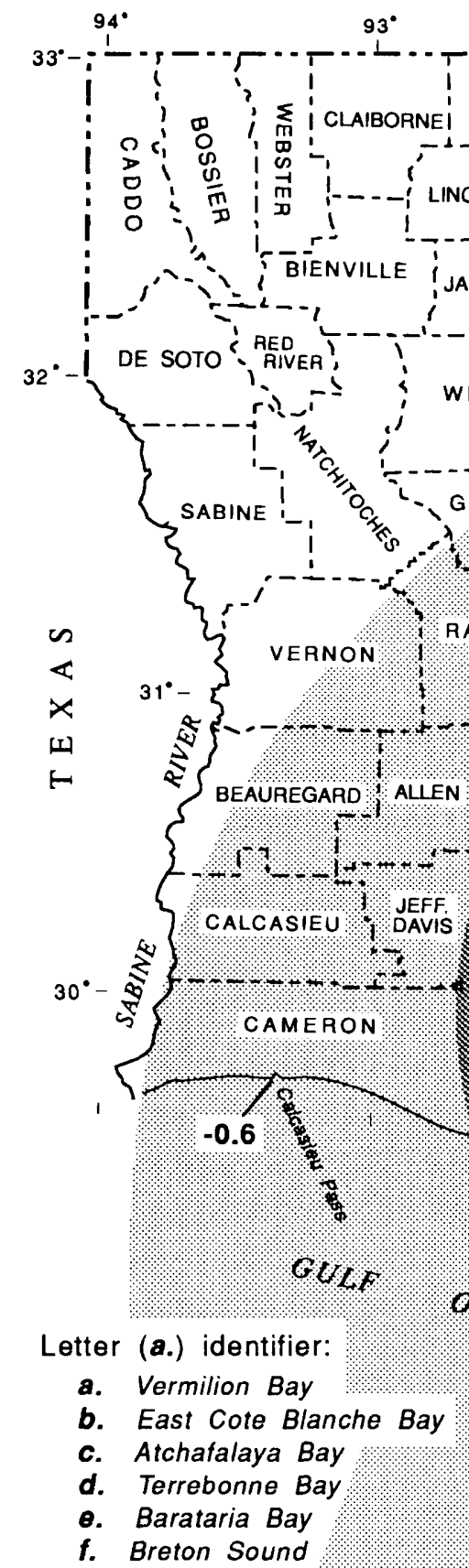

\section{EXPLANATION}

EXTENT OF TROPICAL

EXTENT OF HURRICANEFORCE WINDS

STORM TRACK

26th, 7pm DATE, IN AUGUST 1992, AND TIME OF DAY

9.3 STORM-TIDE ELEVATION, IN FEET ABOVE SEA LEVEL 26th, 7pm

MIS SI S S I P P I 


\section{Presentation of Data}

Data for the high-water marks are presented in tables and plotted on twelve $30 \mathrm{X} 60$-minute quadrangle maps as a series of plates. Tabular data include plate number, quadrangle name, mark number, nearest town, latitude, longitude, quality and reliability of mark (good, plus or minus 0.10 $\mathrm{ft}$; fair, plus or minus $0.25 \mathrm{ft}$; poor, greater than $0.25 \mathrm{ft}$ ), type of mark, location of mark (inside or outside), water-surface elevation, and ground-surface elevation. The plates show the locations and elevations of the high-water marks. Locations and boundaries of the $30 \times 60$-minute quadrangle maps are shown in figure 2.

Storm-tide data from 76 continuous gaging stations also are presented in tabular form and plotted on the quadrangle maps. Tabular data include the plate number, quadrangle name, gagingstation number, owner, owner number, station name, latitude, longitude, and the date, time, and elevation of the peak storm-tide measurement. The quadrangle maps show the gage locations and date, time, and elevations of peak storm-tide measurements. In addition, time-series data of stage and either specific conductivity or stream velocity from 24 of the 76 continuous gaging stations are shown as line graphs. The locations of these gaging stations are shown in figure 3.

\section{Acknowledgments}

This report was made possible with the assistance and cooperation of many home and property owners who allowed high-water-elevation surveys to be made. Special thanks are extended to Dennis Lee, FEMA; John Miller, COE; and Bob Zurflugh, National Geodetic Survey.

\section{METHODS}

Immediately after Hurricane Andrew passed, USGS crews located and documented highwater marks in the coastal areas of Louisiana. Each high-water mark was flagged or marked, described in detail, and photographed. The description of each mark included its geographical and physical location, type of mark (seedline, washline, driftline, stainline, or debris), and an assessment of the quality of the mark. The quality of each mark was determined as follows (Shuck-Kolben, 1990, p. 4):

\begin{tabular}{clc}
\hline $\begin{array}{c}\text { Quality of } \\
\text { mark }\end{array}$ & \multicolumn{1}{c}{ Description } & Rellability \\
\hline Good & A level, well-defined line of densely accumulated fine debris or a distinct stain & $0.10 \mathrm{ft}$ \\
Fair & A level, but less distinct band of fine to coarse debris or stain & $0.25 \mathrm{ft}$ \\
Poor & $\begin{array}{l}\text { A poorly defined band of sparsely accumulated coarse debris that may undulate due to } \\
\text { surface-wave action. Other examples include a discontinuous scatter of coarse debris } \\
\text { on a structure, a coarse groundline of heavy-vegetative drift, or debris hung in the } \\
\text { branches of a tree. }\end{array}$ & $>0.25 \mathrm{ft}$ \\
\hline
\end{tabular}


A R K A N A S

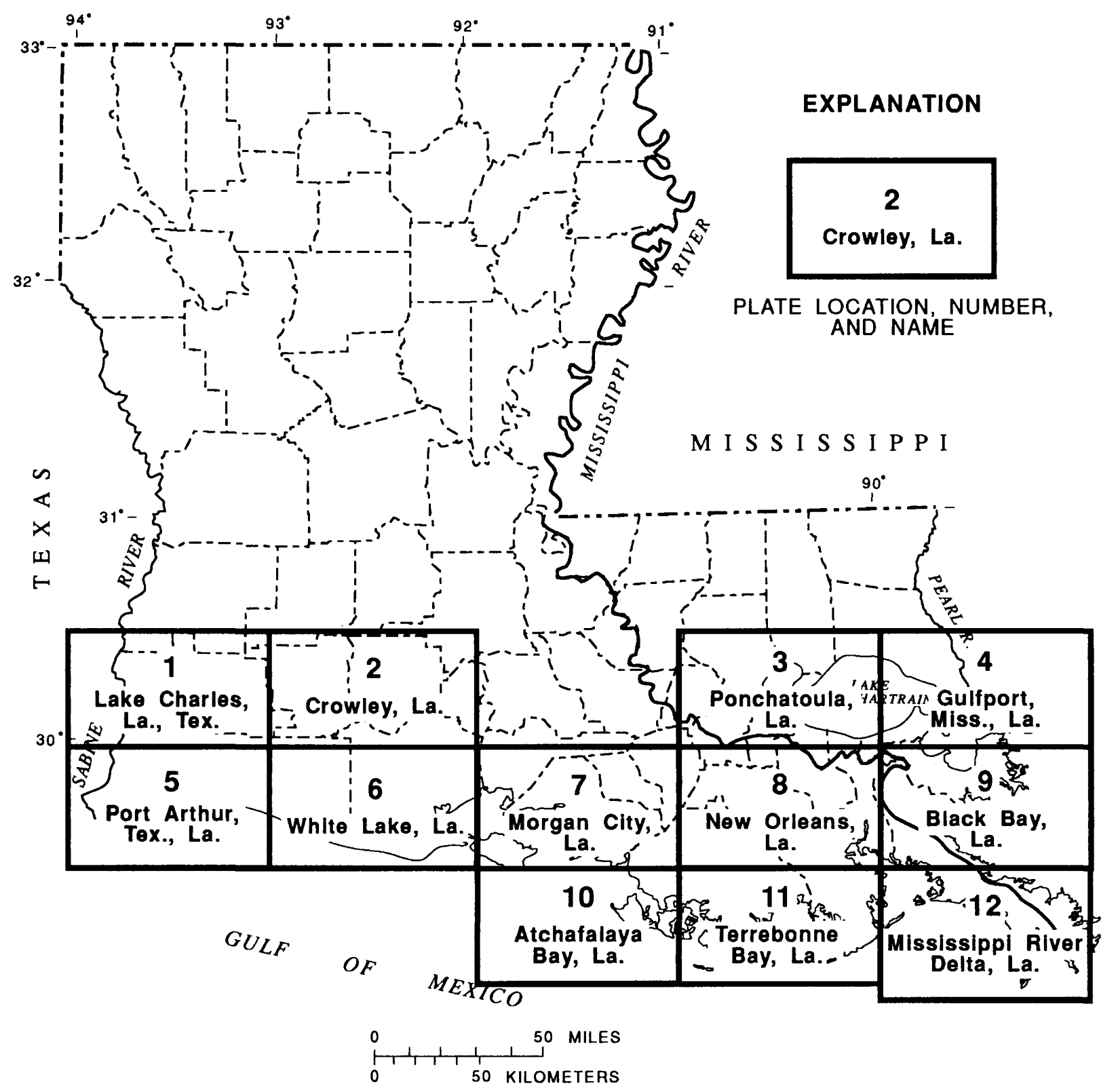

Figure 2. Locations and boundaries of quadrangles for which storm-tide elevations are shown. 
A R K A N S A S

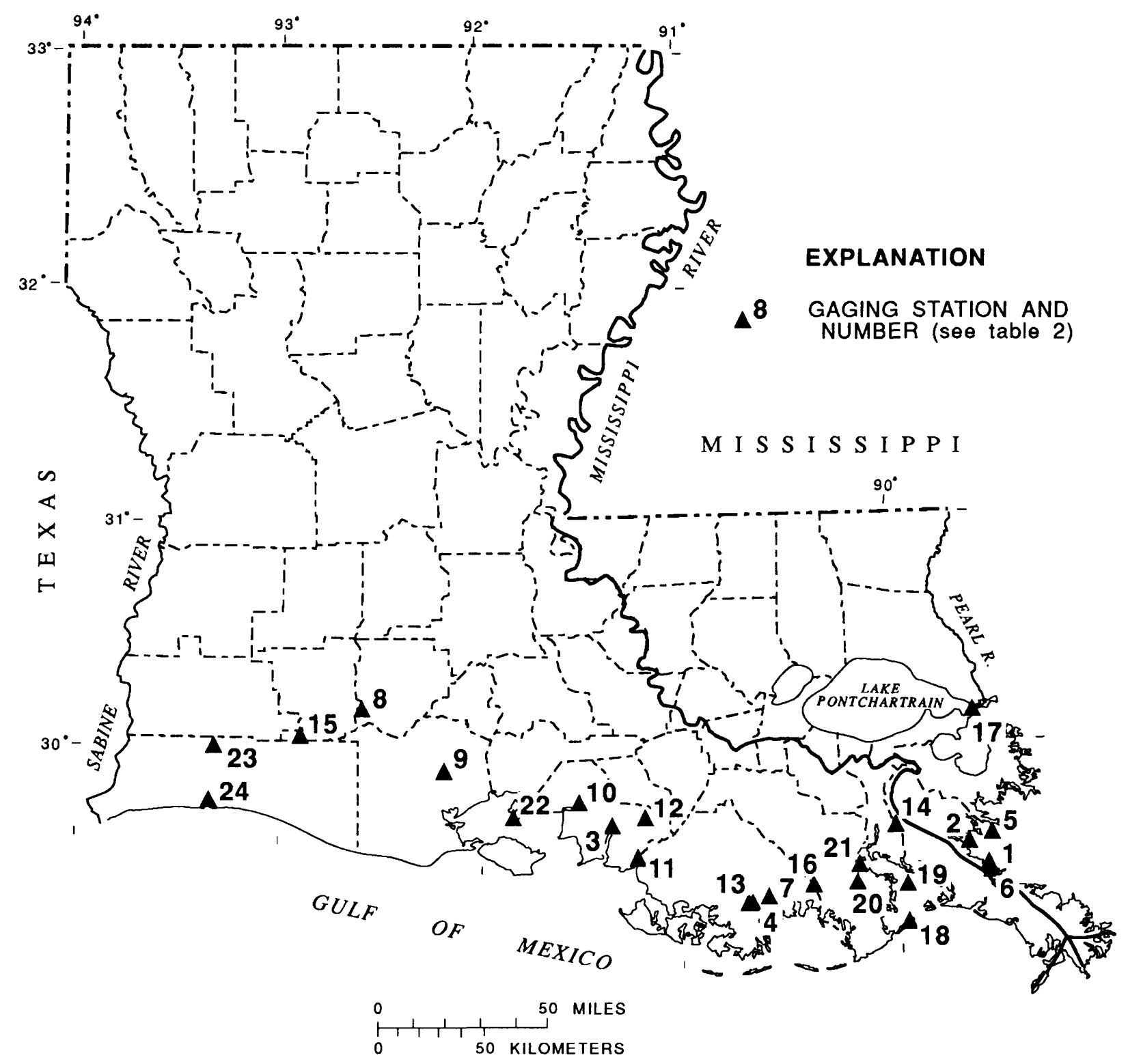

Figure 3. Location of selected gaging stations from which time-series data are presented. 
During the next phase of the study, surveying crews obtained elevations for each of the highwater marks flagged. All of the elevations documented in this report were obtained using conventional level equipment and vertical control stations (bench marks).

Global Positioning System (GPS) equipment also was used to determine elevations for many high-water marks located in marsh areas, on barrier islands, and in other remote areas without bench marks. However, the elevations obtained using GPS were not included in the data set because they were not as reliable as most of the elevations that were obtained by conventional methods.

\section{VERTICAL DATUM}

The National Geodetic Vertical Datum of 1929 (NGVD of 1929) was used as the datum for this study. NGVD of 1929 is a geodetic datum derived from a general adjustment of the first-order level nets of both the United States and Canada. Although the datum was derived from the average sea level over a period of many years at 26 tide stations along the Atlantic, Gulf of Mexico, and Pacific Coasts, NGVD of 1929 does not necessarily represent local mean sea level at any particular place (Arcement and others, 1991, p. 35). NGVD of 1929 is referred to as "sea level" in the remainder of this report.

Bench-mark elevations used for this study were obtained from the National Geodetic Survey and the Terrebonne Parish Department of Public Works. Because coastal regions of southern Louisiana are subsiding (Andel and Curray, 1960), bench-mark elevations need to be adjusted regularly. An enormous effort is required for updating bench-mark elevations and was beyond the scope of this study. Consequently, the accuracy of high-water-mark elevations is limited by the accuracy of the bench-mark elevations used as vertical control points.

\section{STORM-TIDE ELEVATIONS}

Hurricane Andrew made landfall in Louisiana at Point Chevreuil near high tide. The storm tide affected much of the Louisiana coastline, including many coastal waterways and lakes hydraulically connected to the coast. The counter-clock-wise motion of the hurricane winds produced a positive storm tide along the Louisiana coast east of landfall, and a negative storm tide west of landfall. Approximate storm-tide elevations (in feet above sea level) along the Louisiana coast were as follows: Lake Pontchartrain, 4; Breton Sound, 5; Barataria Bay, 4; Grand Isle, 4; Terrebonne Bay, 9; Atchafalaya Bay, 8; East Cote Blanche Bay, 8; Vermilion Bay, -3; and Calcasieu Pass, -1 (fig. 1).

East of the eye of the hurricane, the counter-clock-wise motion of the winds pushed water landward, causing an abnormally high tide along the coast. From the Mississippi State line to Grand Isle, La., the elevation of the storm tide along the Louisiana coast generally ranged from 3 to $5 \mathrm{ft}$ above sea level. From Grand Isle to Point Chevreuil, La., the elevation of the storm tide along the coast generally ranged from 4 to $9 \mathrm{ft}$ above sea level. The storm tide peaked at $8.2 \mathrm{ft}$ above sea level near landfall and at $9.3 \mathrm{ft}$ above sea level near Cocodrie, La., which is located about $60 \mathrm{mi}$ east-southeast of the point of landfall (fig. 1).

West of the eye of the hurricane, the winds pushed water southward, away from the coast, producing a negative storm tide that left no marks, but was recorded by gages along the coast. From landfall to the Texas State line, the negative storm tide generally ranged from 0.5 to $3 \mathrm{ft}$ be- 
low sea level. The lowest measurement, $3.3 \mathrm{ft}$ below sea level, was recorded at a gage located at Cypremort Point, La., about 10 mi east of landfall (fig. 1).

Most of the flood damage caused by the storm tide in Louisiana occurred in southern Terrebonne Parish where the storm tide was highest and the levees are low and discontinuous. Much of this area is comprised of marsh and other wetlands that are mostly unoccupied. The few roads in this area were built on top of naturally occurring levees that trend north-south and most of the population in southern Terrebonne Parish lives along these roads. Most of the high-water marks collected for this report were obtained from houses and other structures located along these ridges. A few high-water marks were documented at fishing camps and other structures in remote locations in the wetlands and along the barrier islands of southern Terrebonne Parish. However, attempts to survey these sites using GPS did not result in the desired level of accuracy, and, consequently, these sites were omitted from this report.

The high-water-mark elevations are shown on $30 \mathrm{X} 60$-minute quadrangle maps (pls. 1-12). The location, storm-tide elevation, and ground-surface elevation at each high-water mark are shown on plates 1 to 12 . Symbols on the plates indicate whether the mark was located inside or outside a structure. Information about each mark, including plate number, water-surface elevation, ground-surface elevation, mark number, mark quality and reliability, type of mark, location of mark (inside or outside), latitude, longitude, quadrangle name, and nearest town are listed in table 1.

High-water marks found inside of structures were generally of much better quality than those found outside because of reduced wind and wave action. If the structure is fairly well closed off from the water, the structure acts as a stilling well, and the "inside" mark represents the still water level, unaffected by the waves. Forty-one ( 59 percent) of the 69 high-water marks documented in this report were found inside of structures. Of the 69 high-water marks, 54 (78 percent) were considered to be of good quality, 8 (12 percent) were considered fair, and 7 (10 percent) were poor (table 1).

Seventy-six continuous gaging stations documented the storm-tide configuration along the coast. Station locations, and date and time of positive and negative peak-storm-tide occurrence are shown on plates 1 to 12 . Information about each gaging station, including plate number, quadrangle name, gaging station number, owner, owner identification number, station name, latitude, longitude, and the date, time, and elevation of the peak storm-tide measurement are listed in table 2.

The water-surface elevation and either specific conductance or stream velocity, if available, for each of the 24 gaging stations during the period of August 22-31, 1992, are shown in hydrographs (figs. 4-27). Some peaks in the hydrographs primarily are due to rainfall runoff, not the storm tide, and the data are not included as maximum positive storm-tide elevations in table 2 and on plates 1 to 12 . In general, gages located east of landfall show a positive storm tide, and gages west of landfall show a negative storm tide. However, a few stations located near landfall, most notably stations 3,11 , and 12 (figs. 6,14 , and 15), recorded both a positive and negative storm tide as the storm moved past them from east to west.

Elevations at gages 1, 2, 5, and 6, for which hydrographs are shown in figures 4, 5, 8, and 9, were estimated because these gages have not been referenced to sea level. The elevations were estimated by matching pre-storm water levels at each gage to pre-storm water levels at gage 59 which is nearby. This estimation is valid with the assumption that the water surface in Breton Sound forms a smooth, continuous surface between the gages. Gage heights at station 7 (fig. 10) were not corrected to sea level and only gage height measurements are shown. 


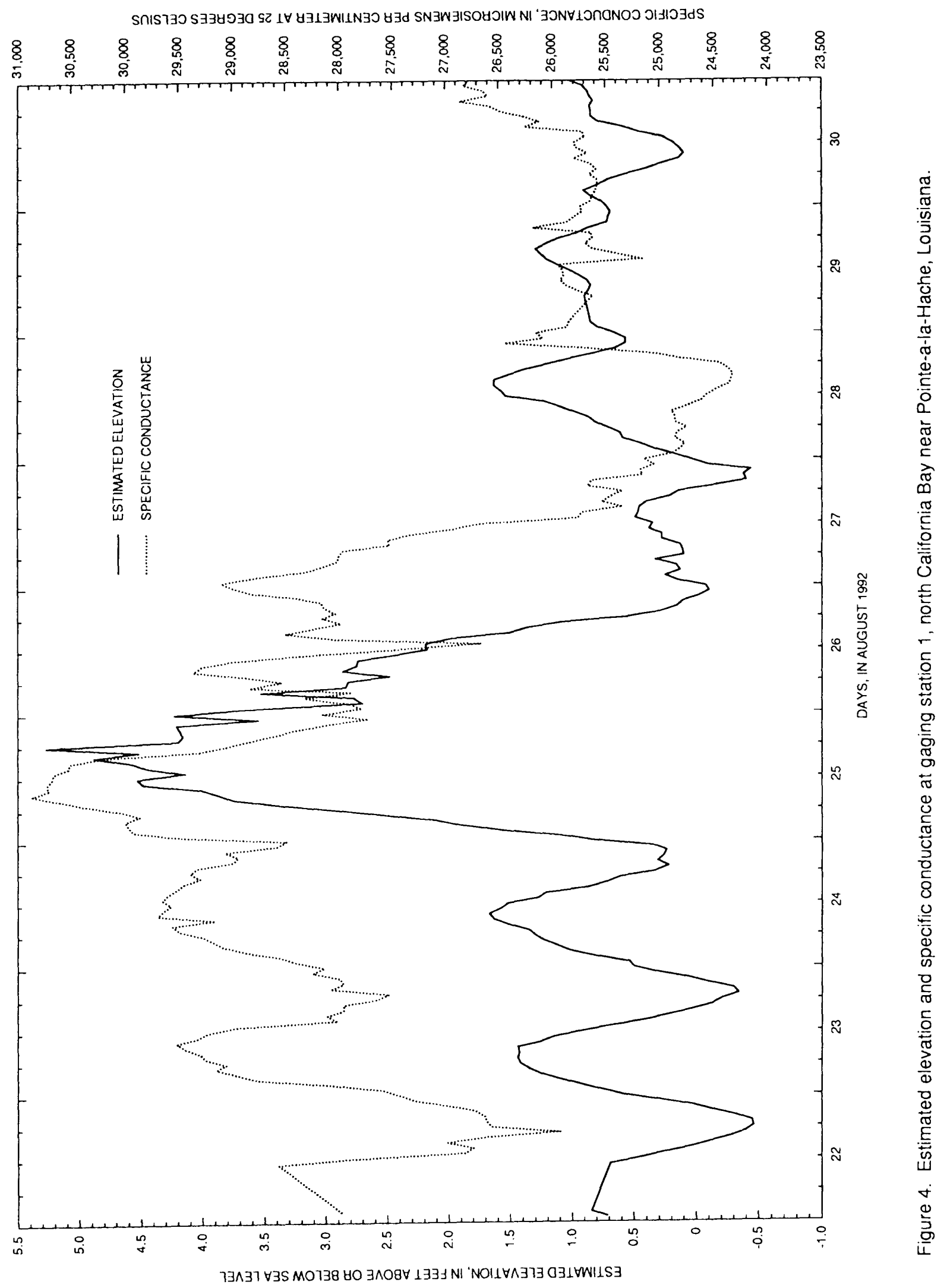




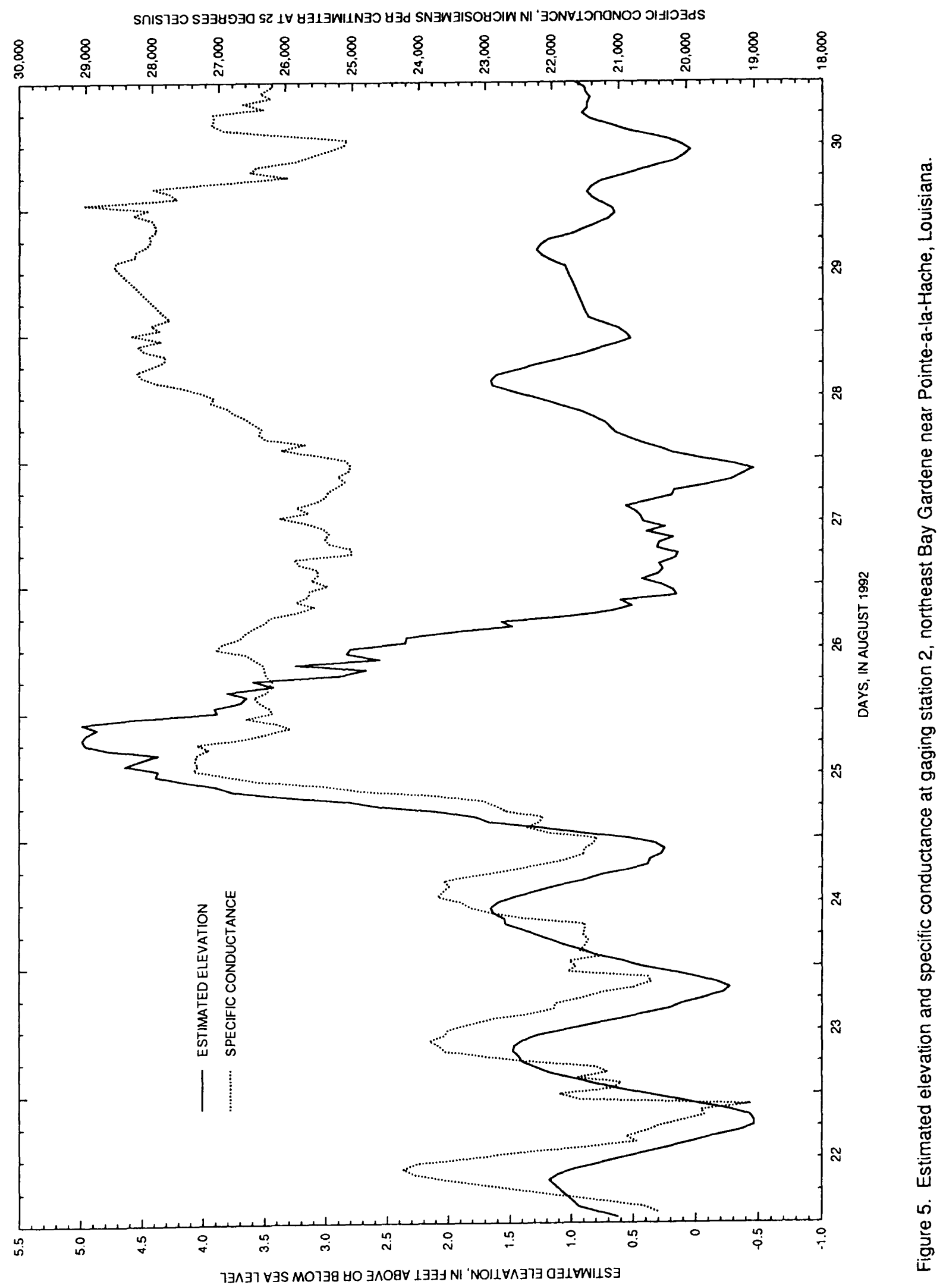




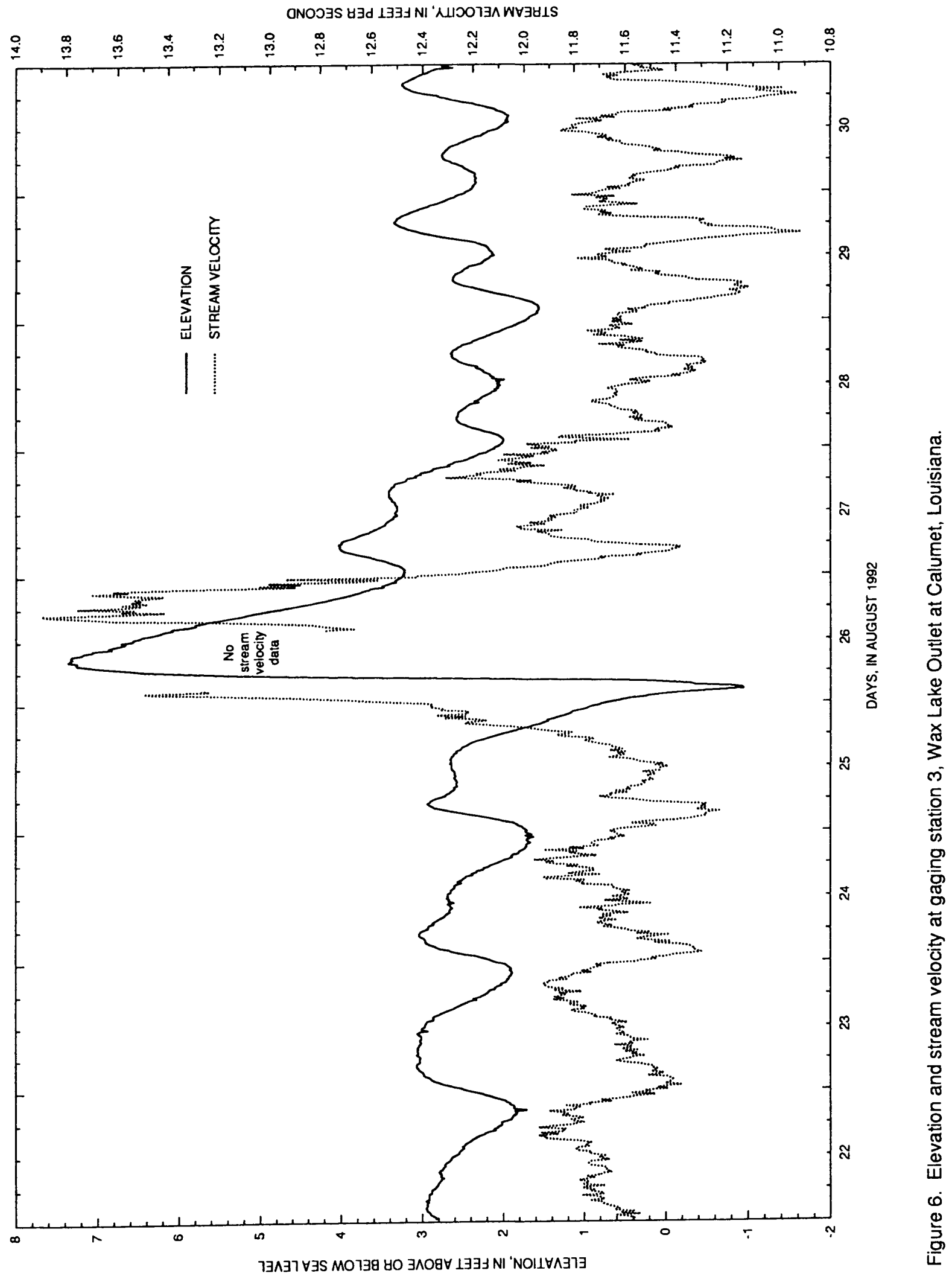




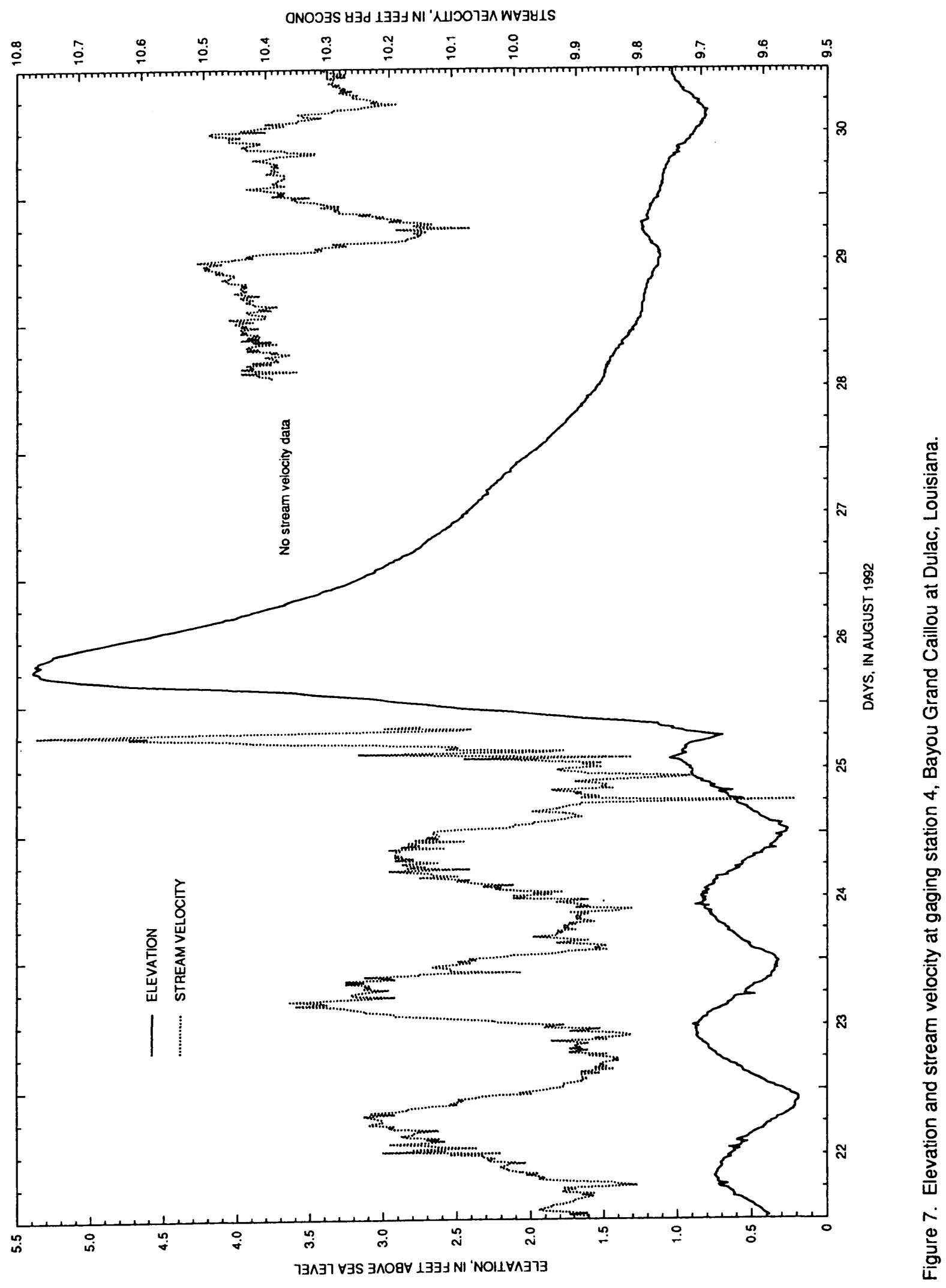




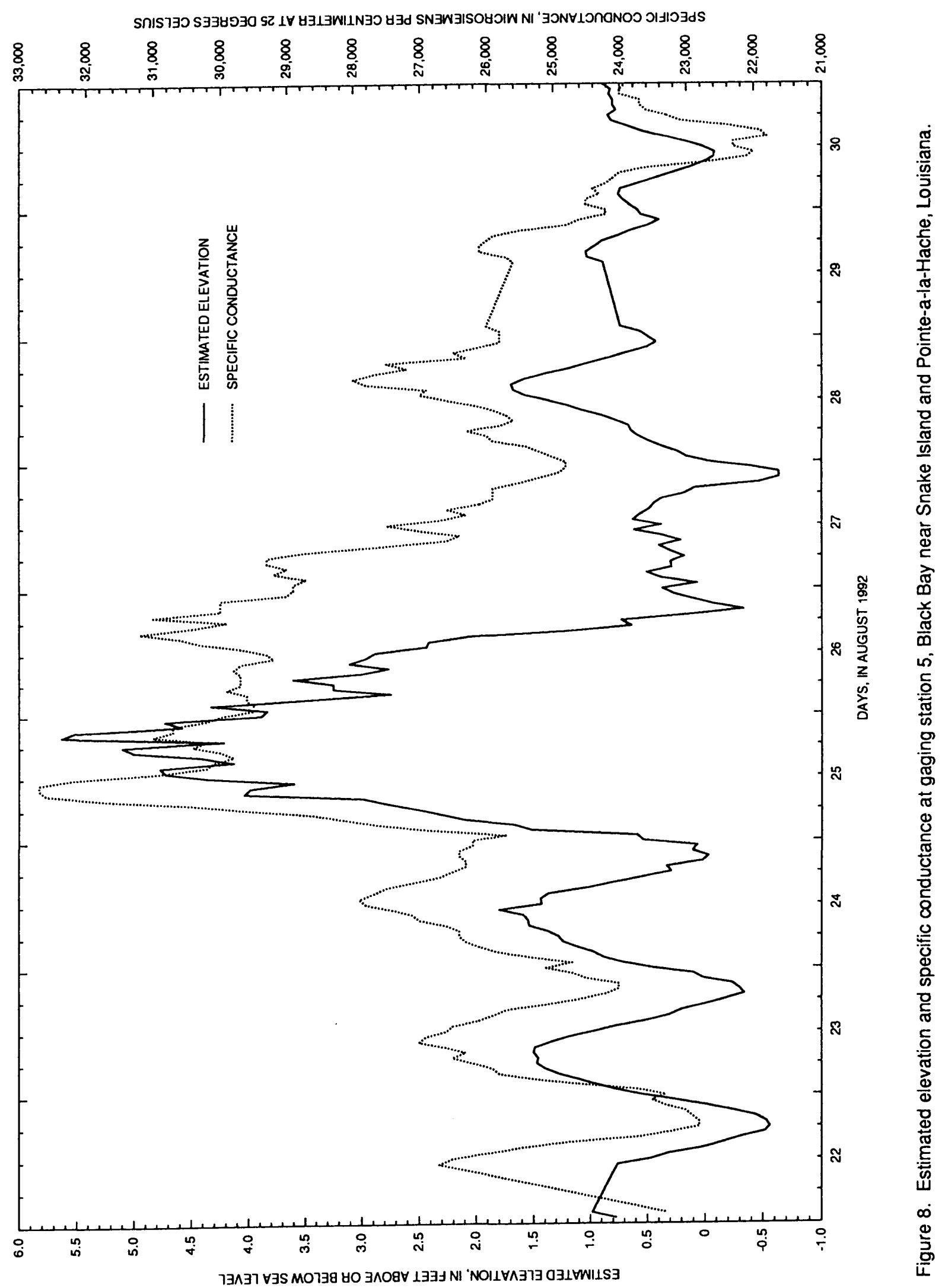




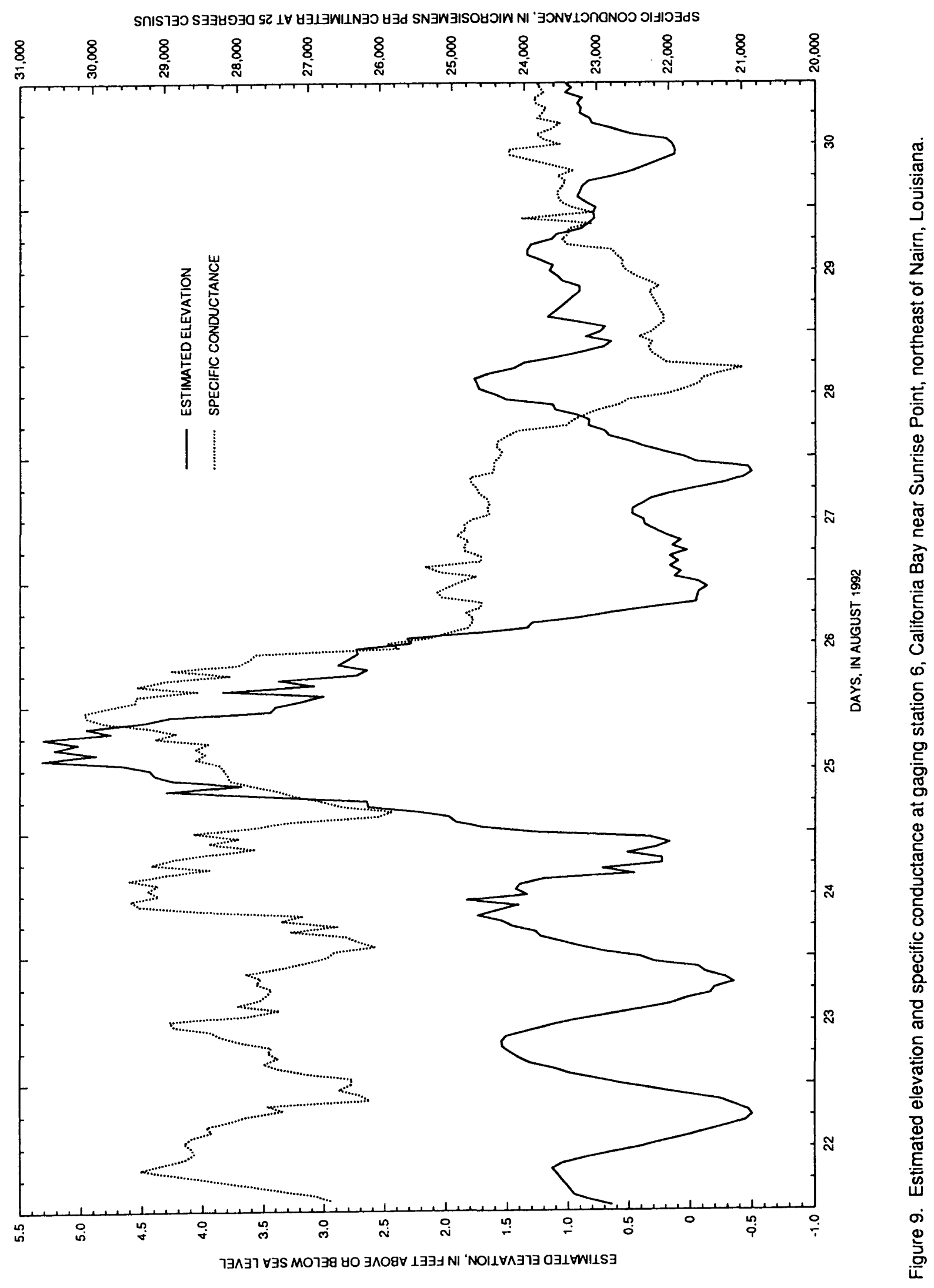




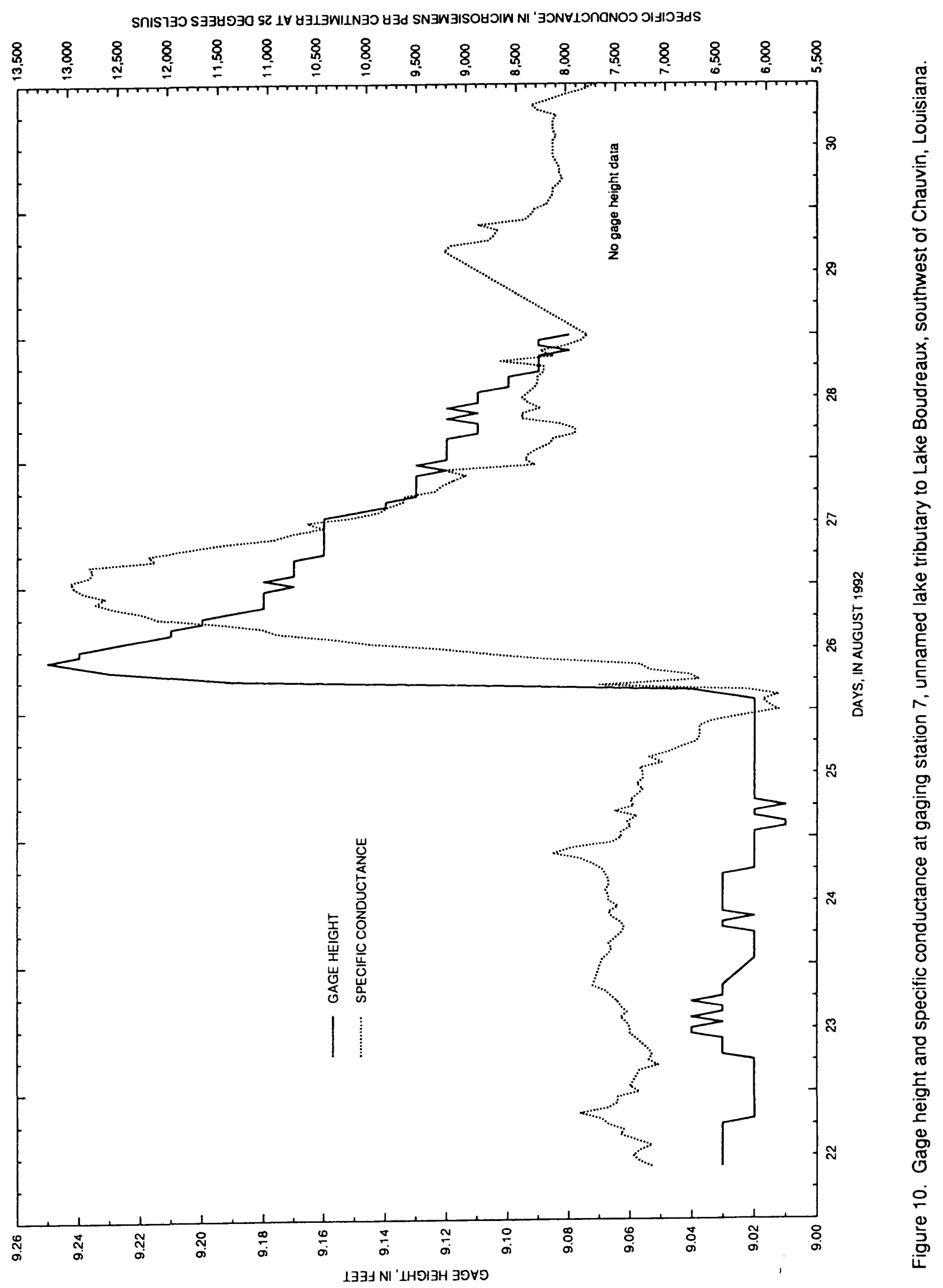




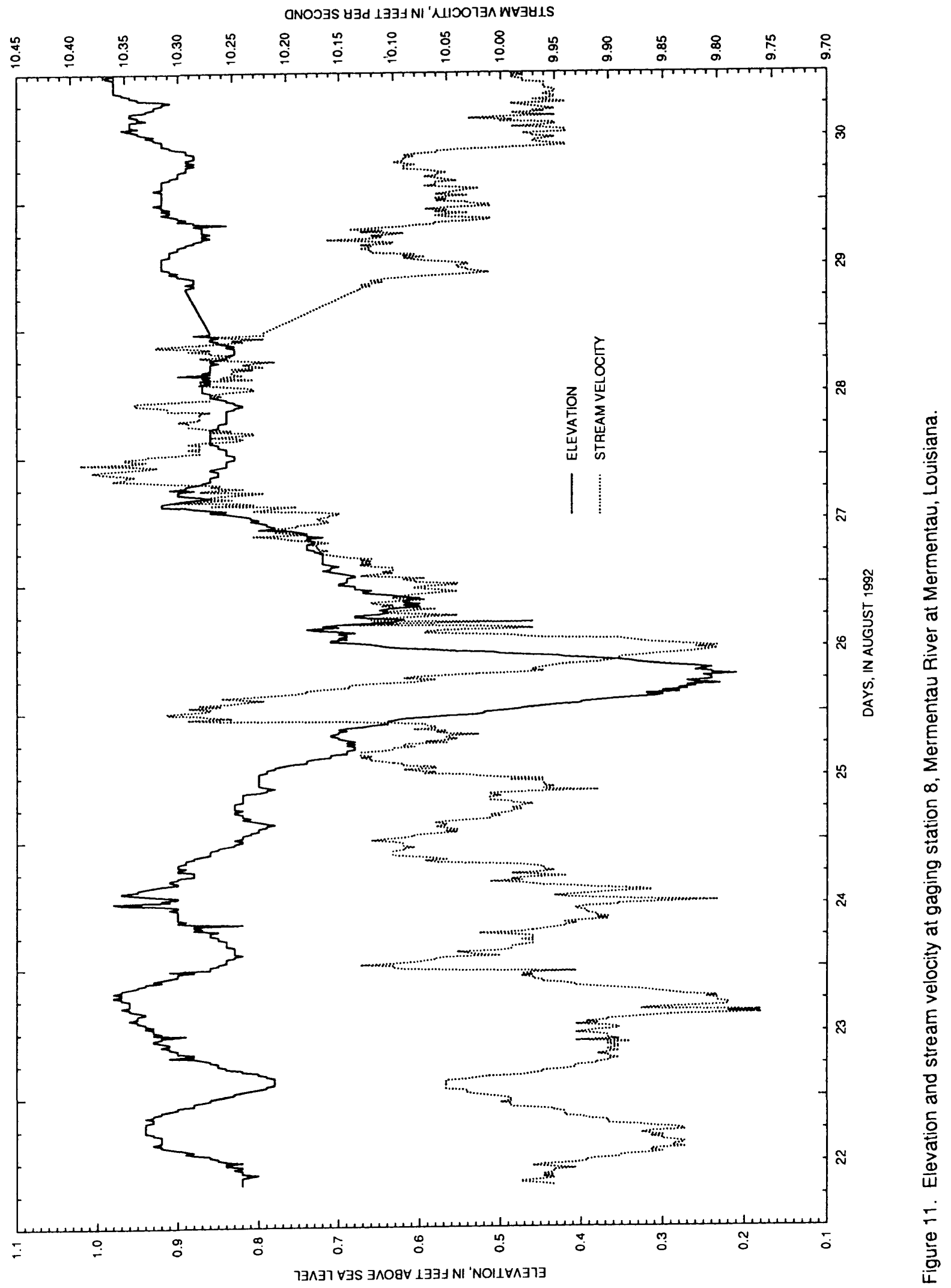




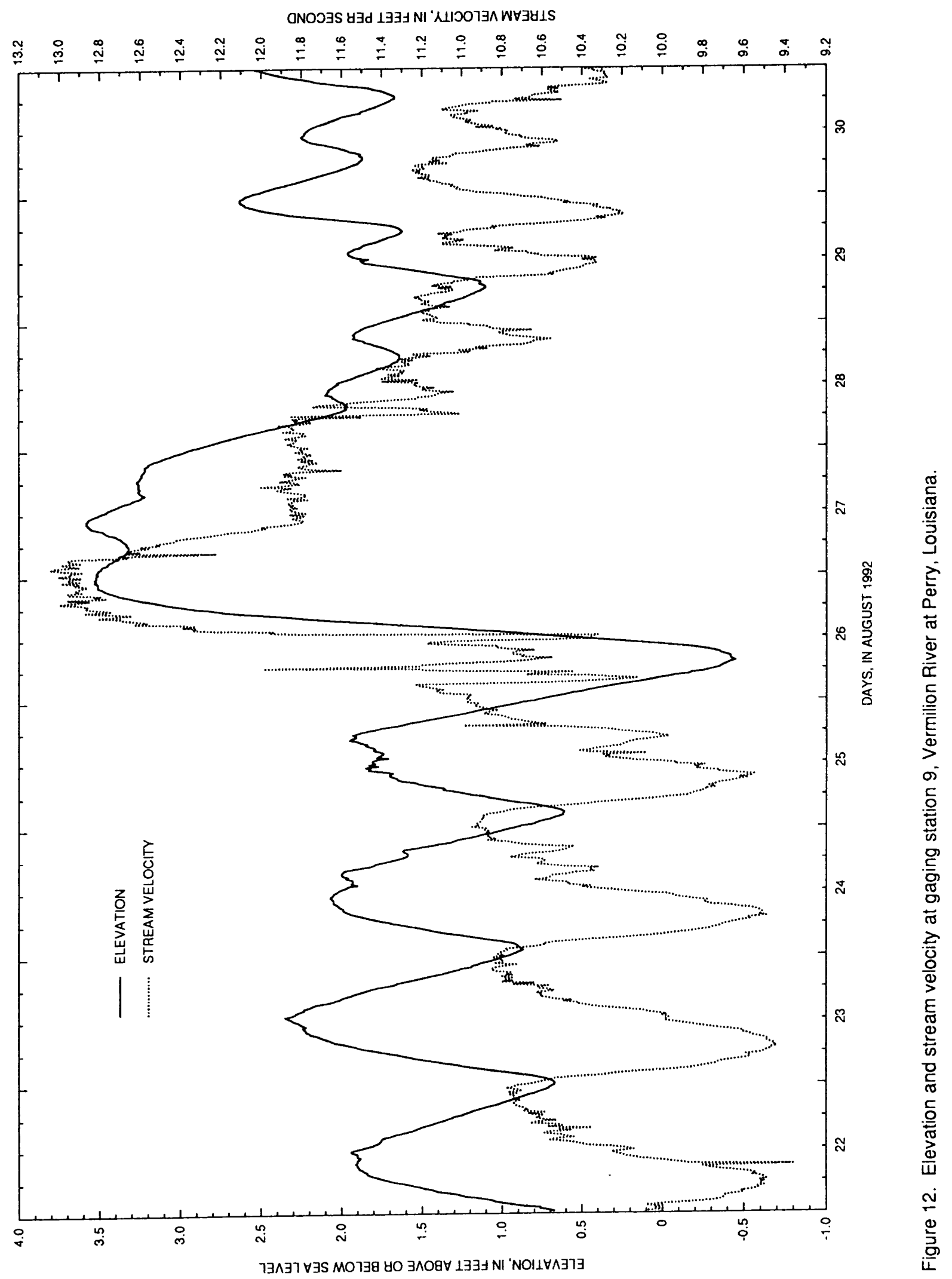




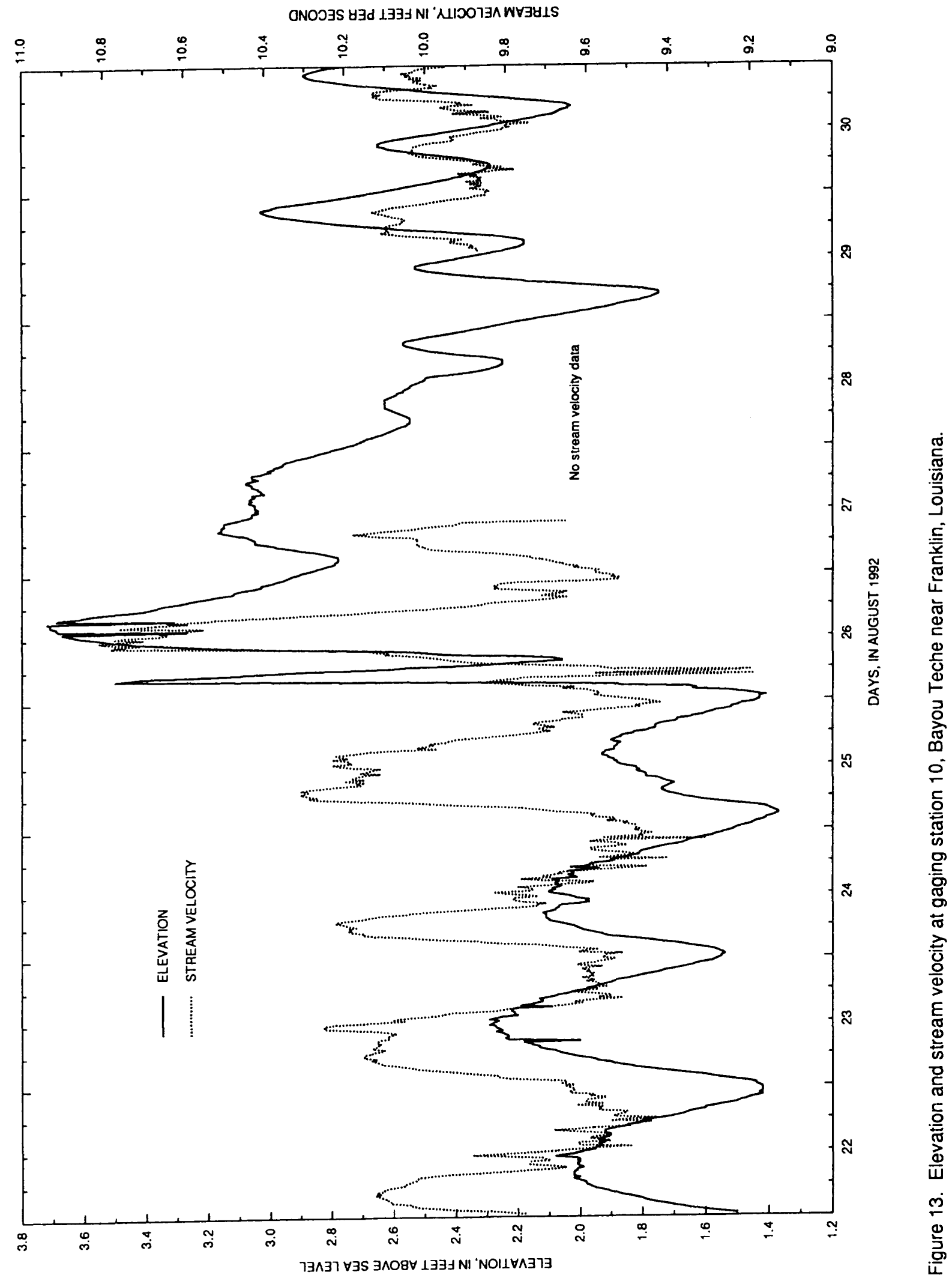




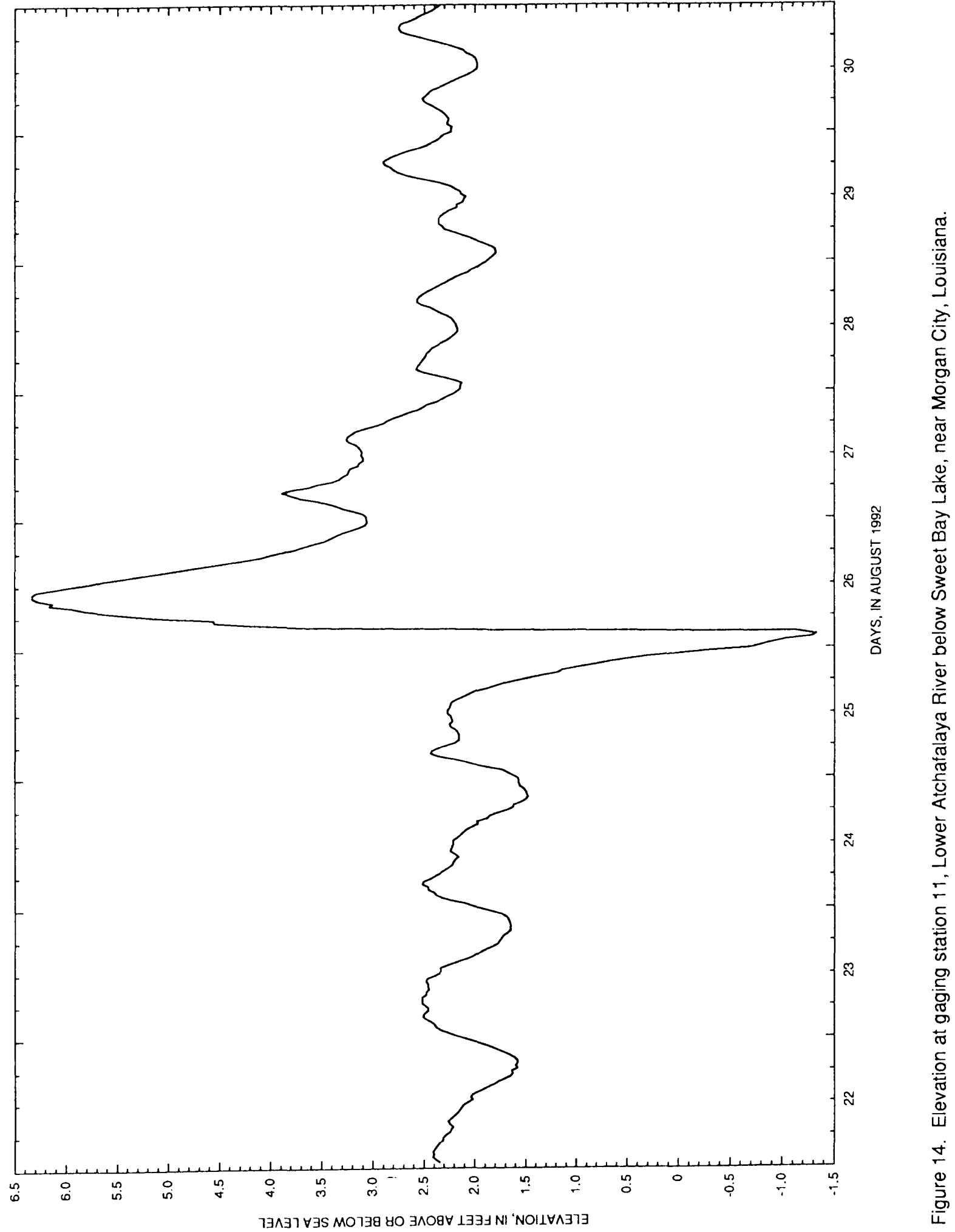

19 


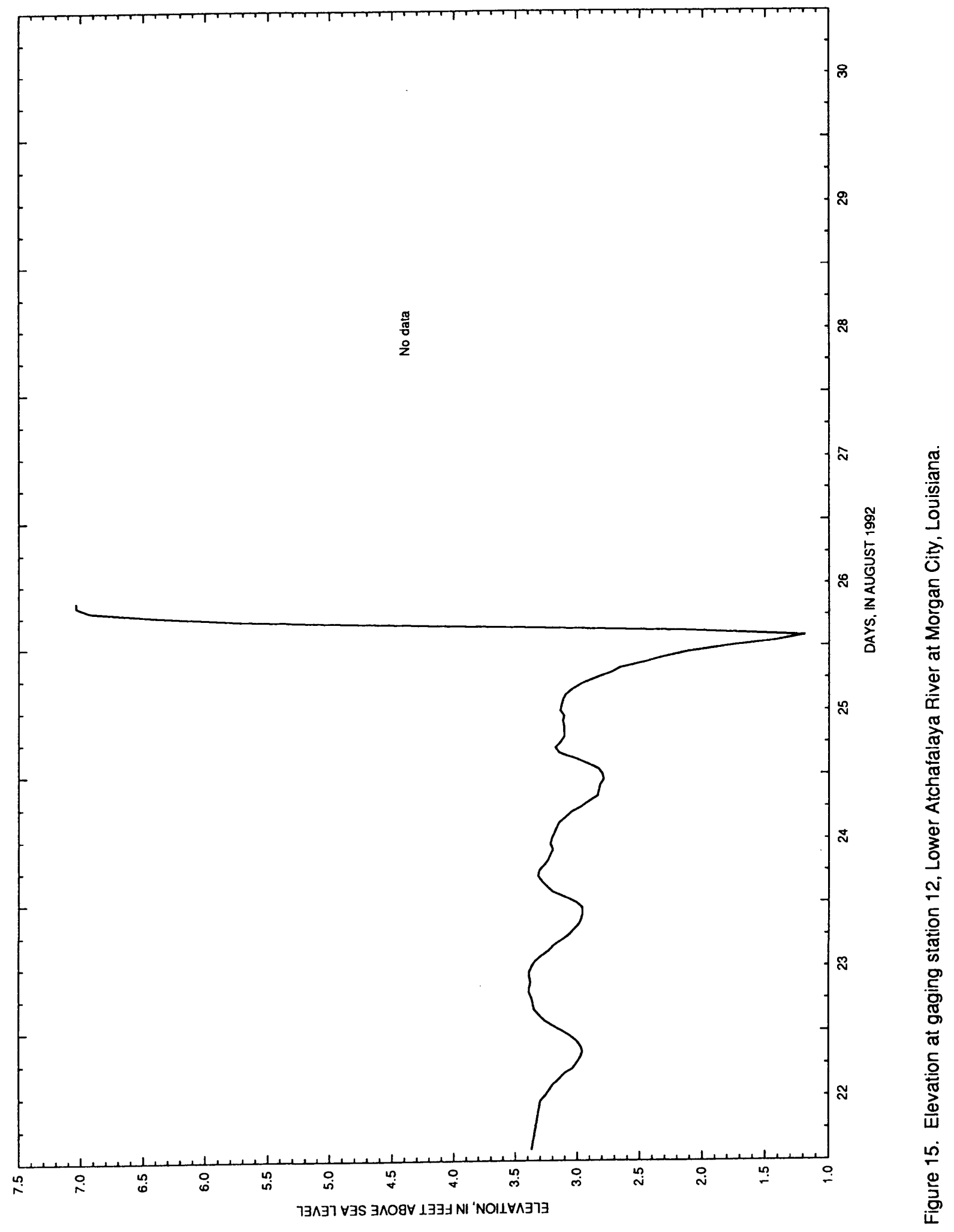




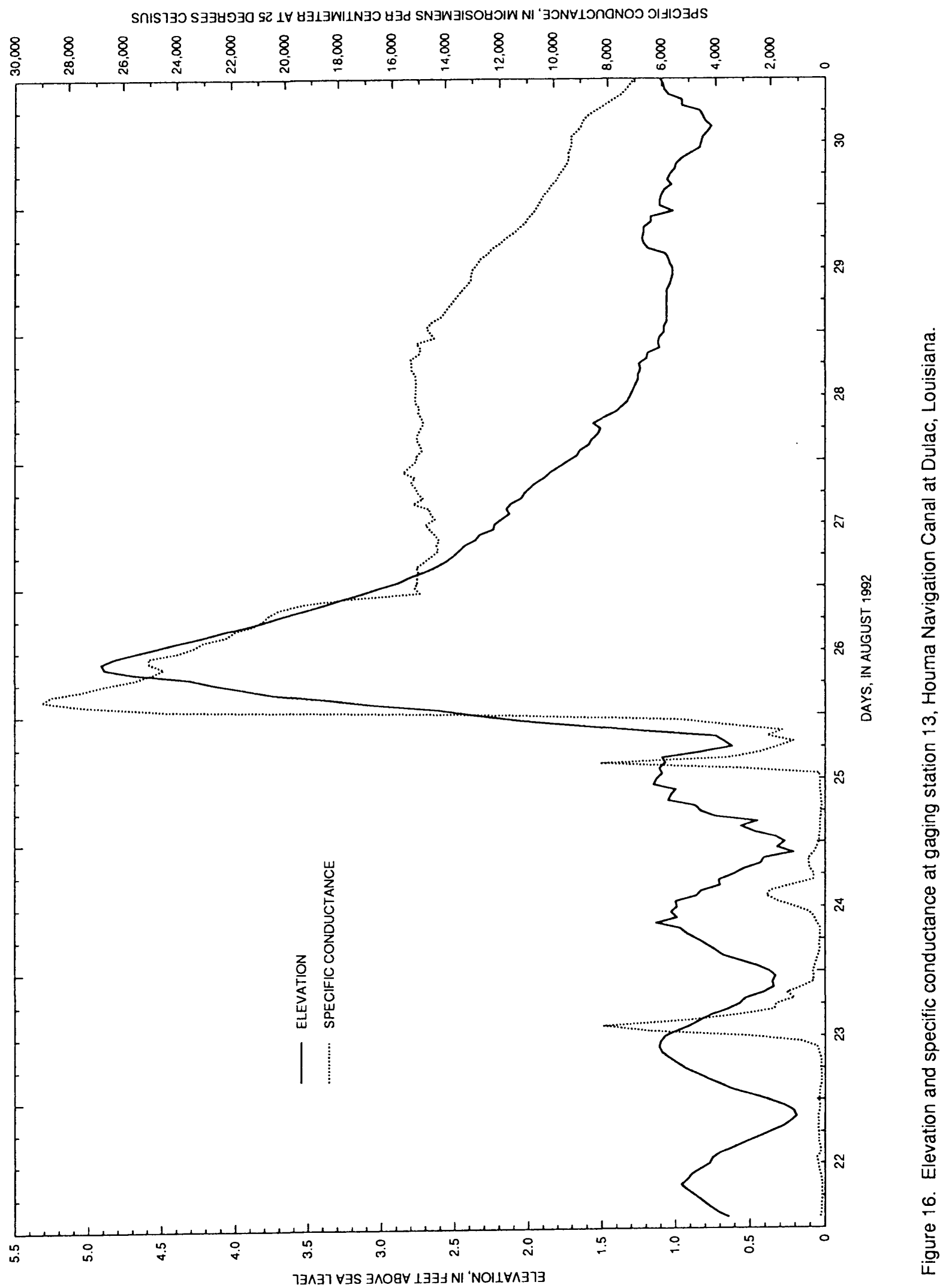




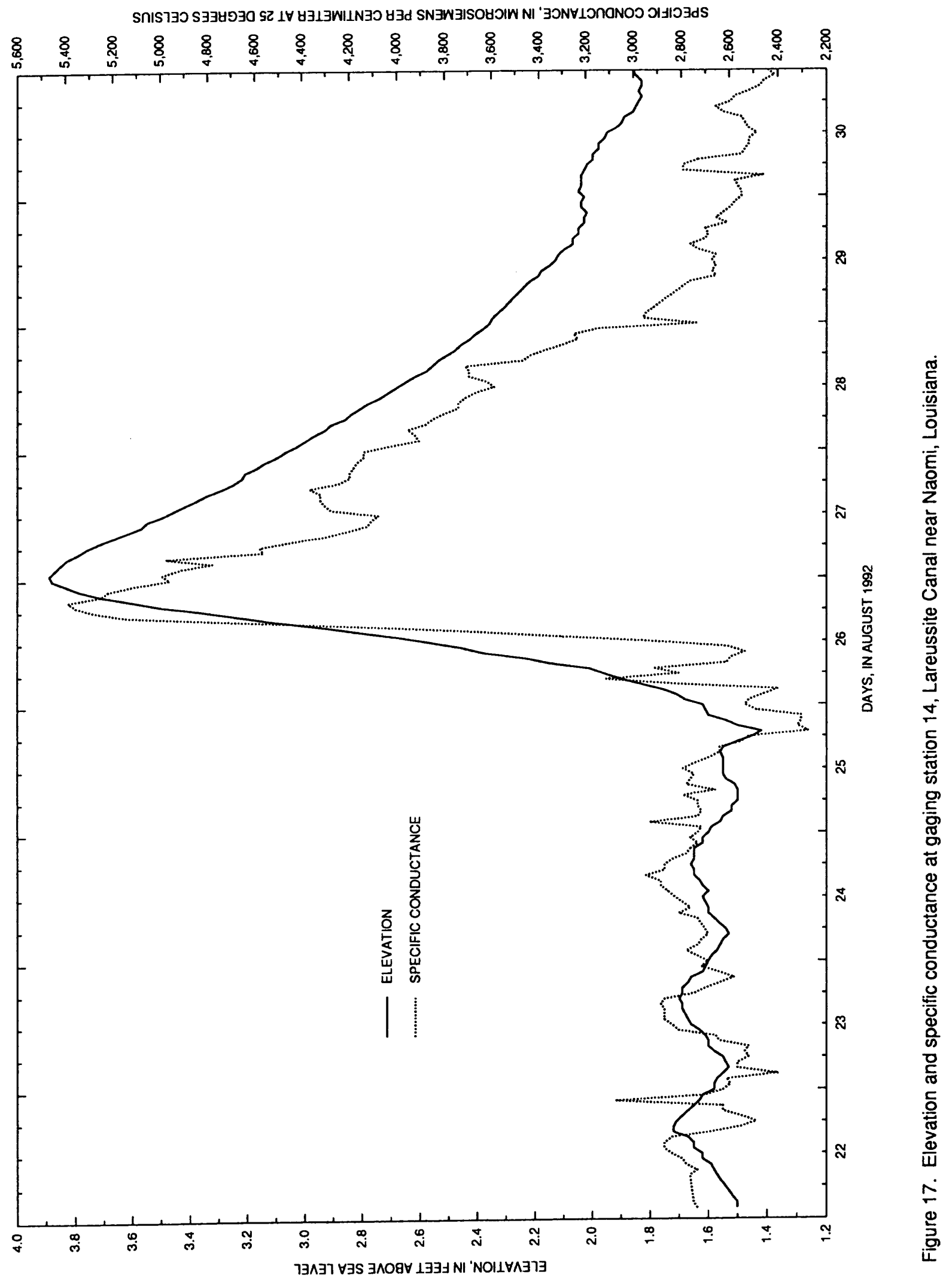




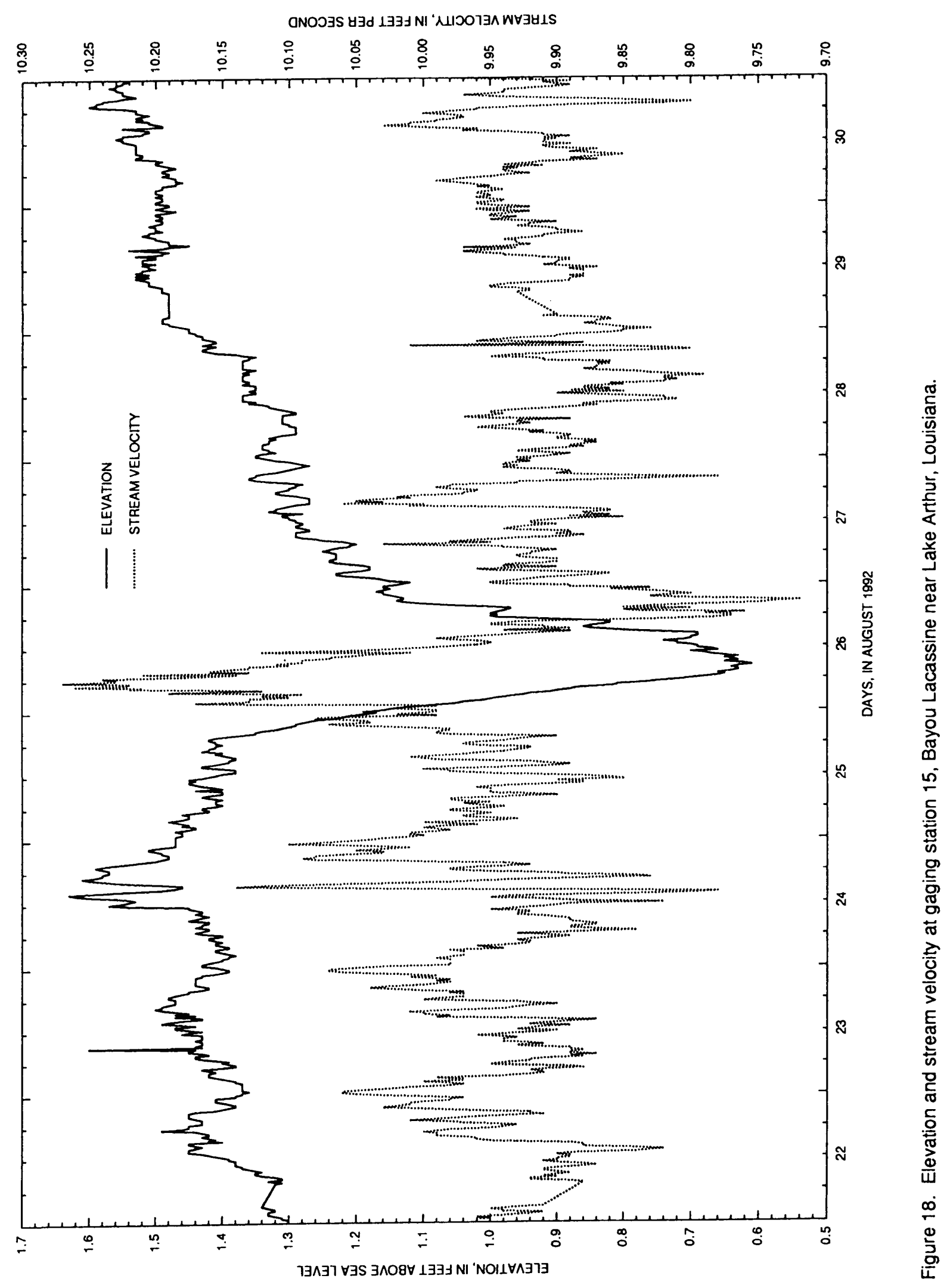




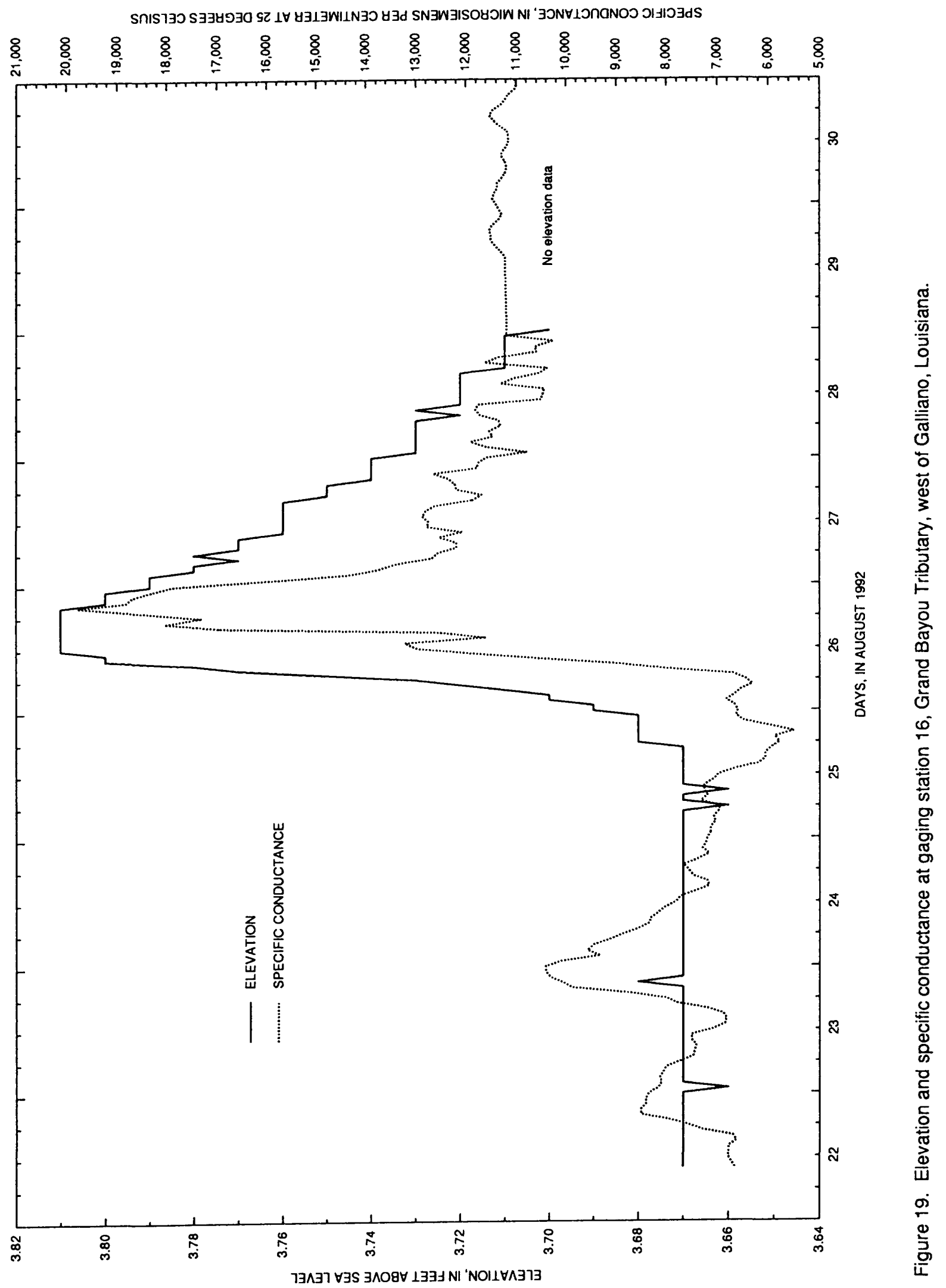




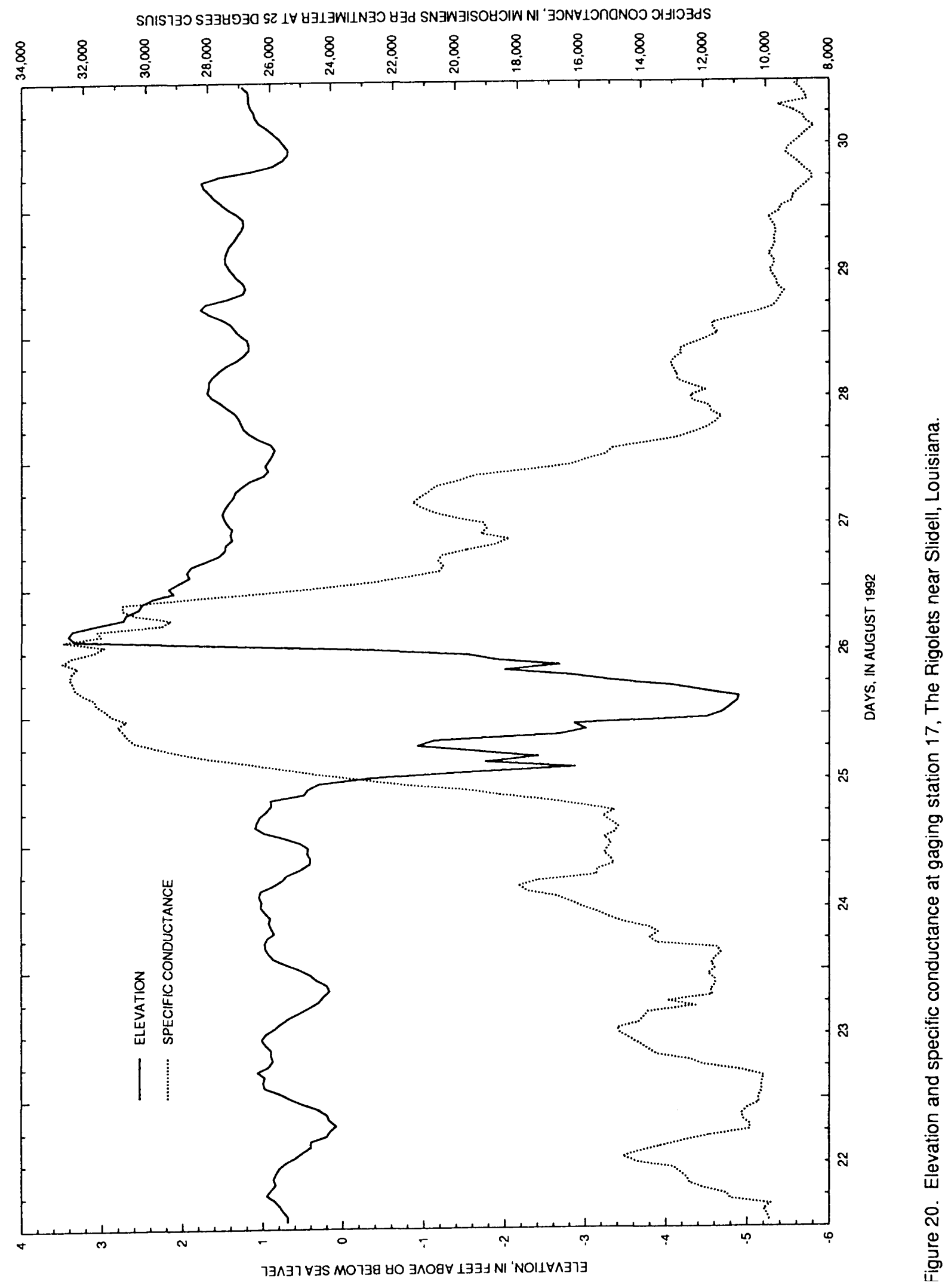




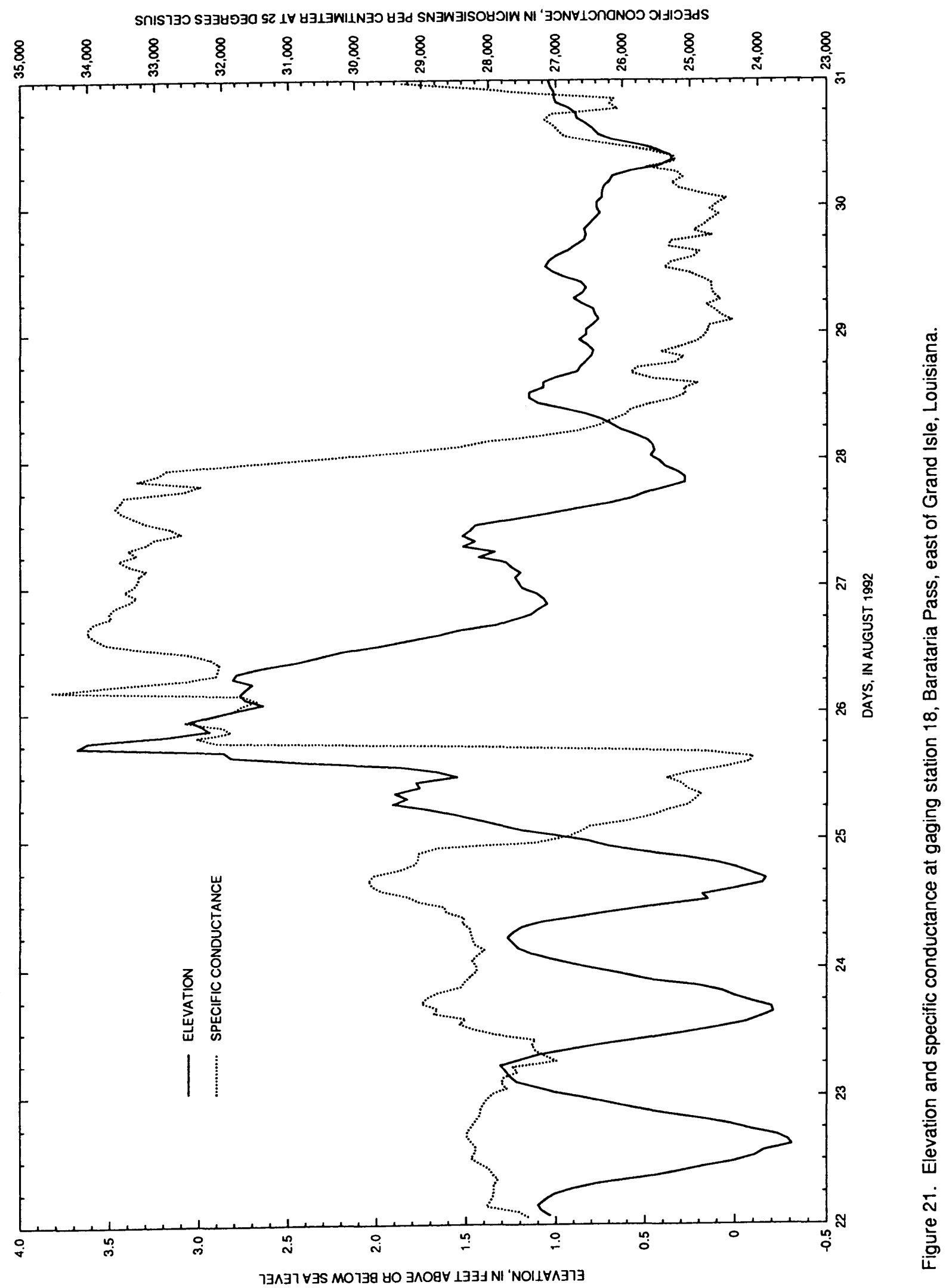




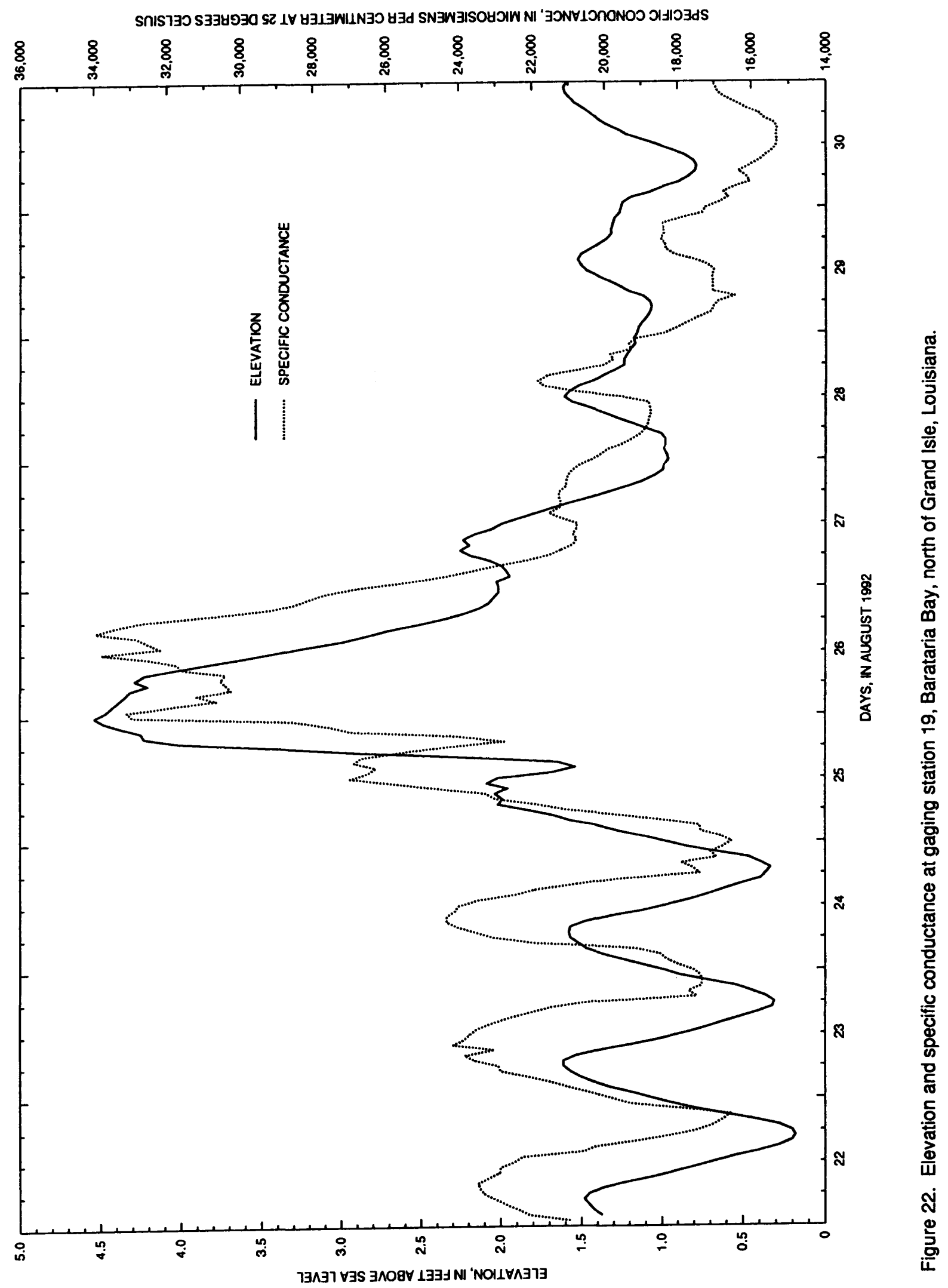




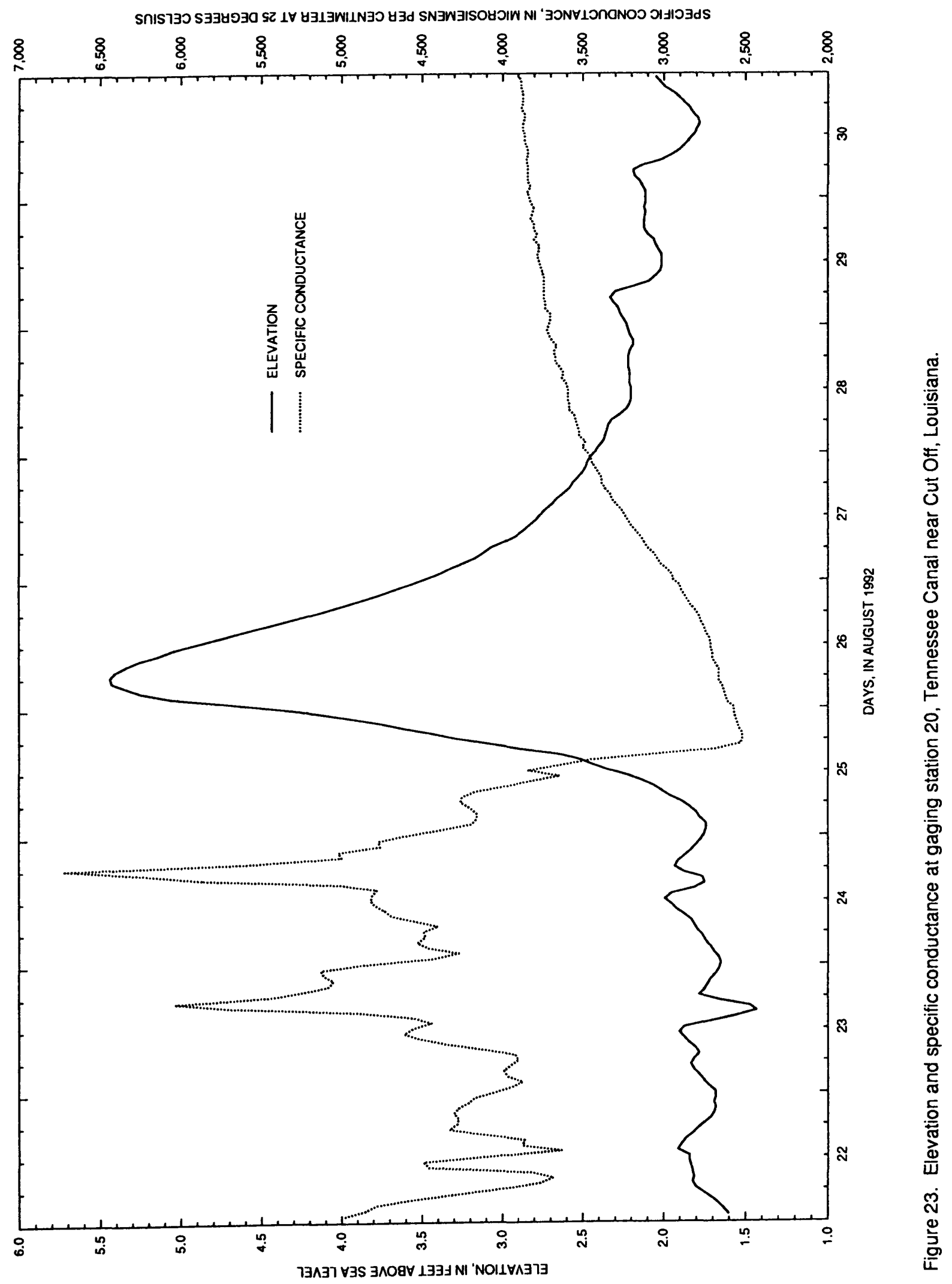




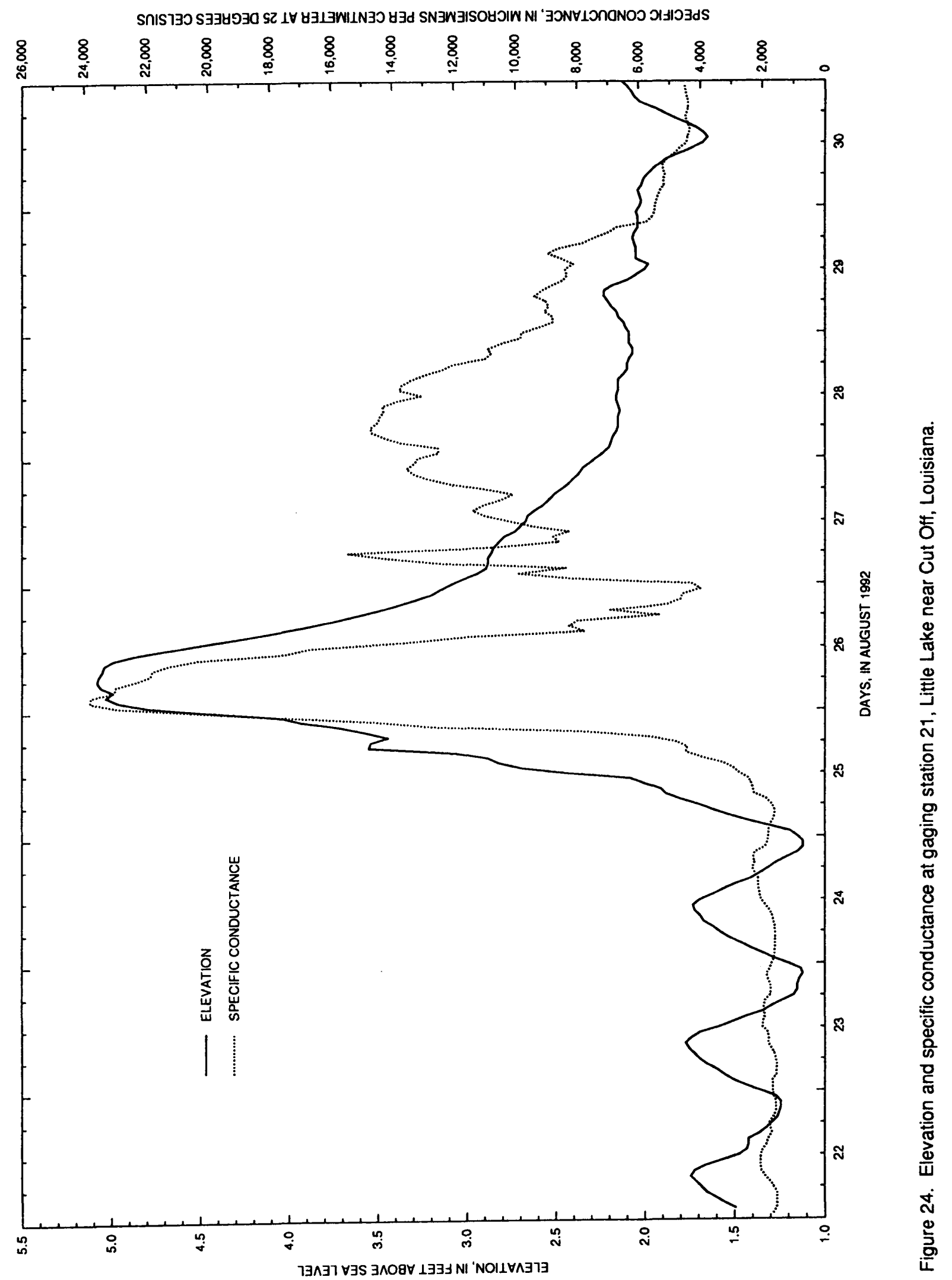




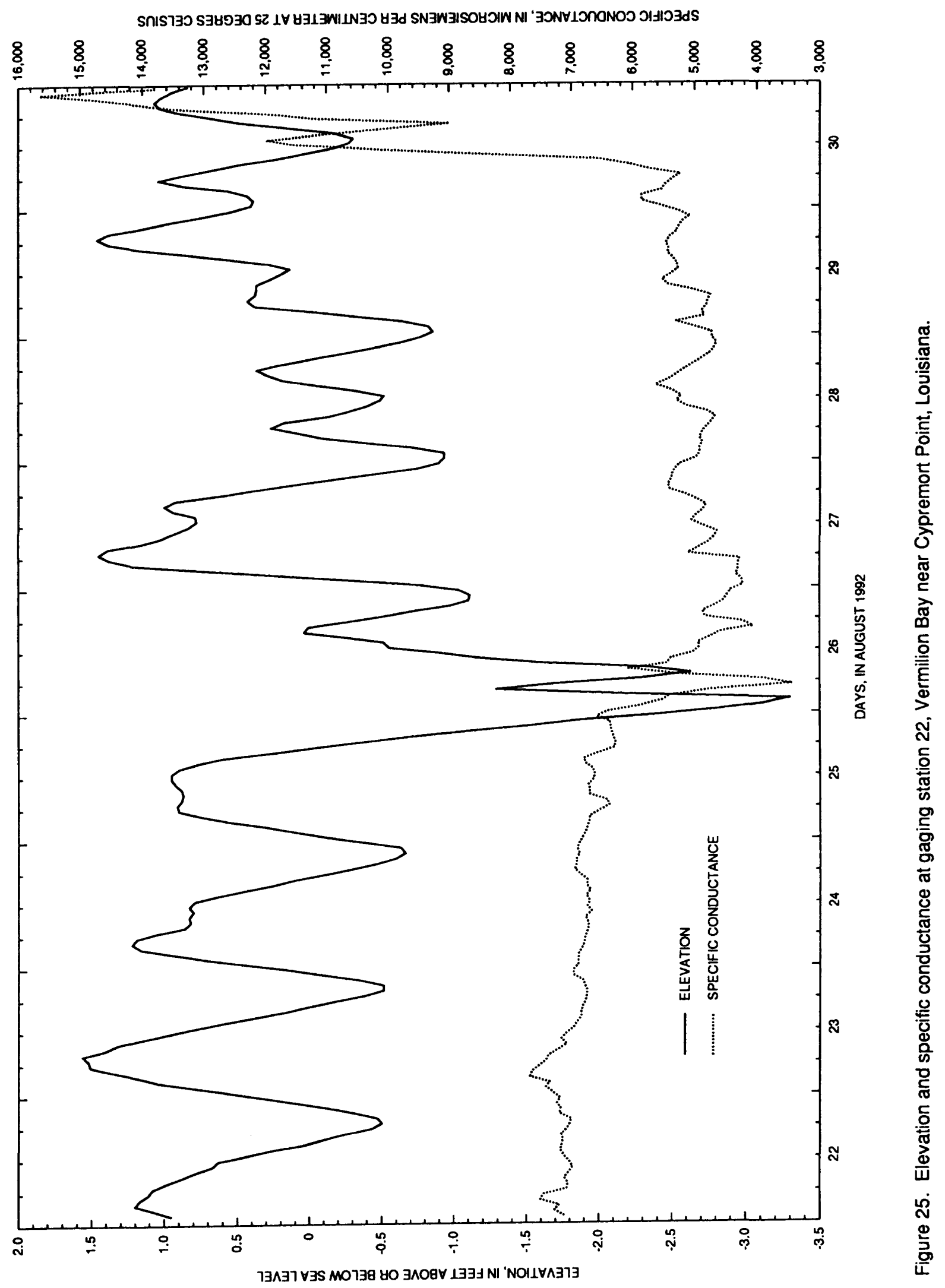




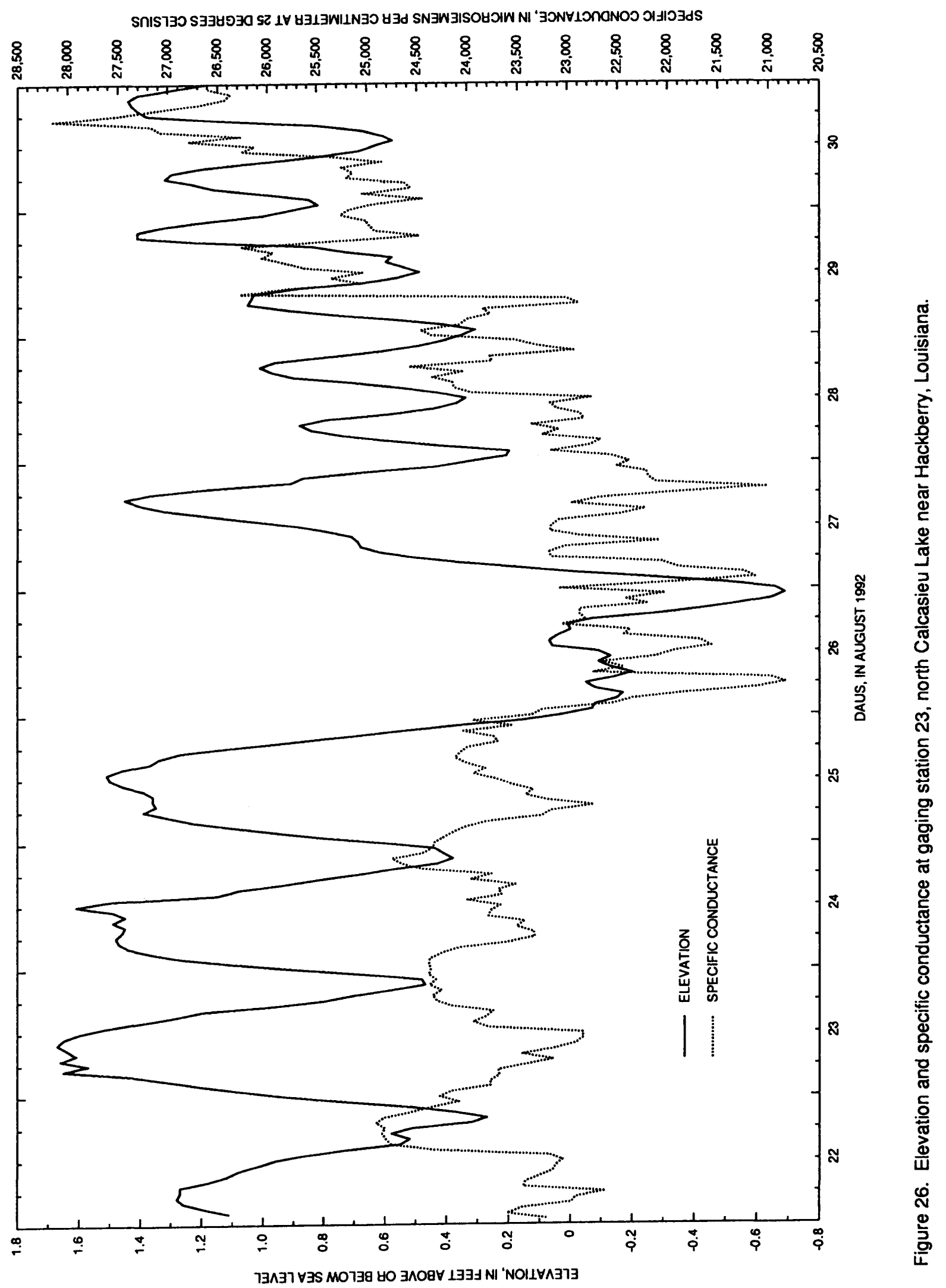




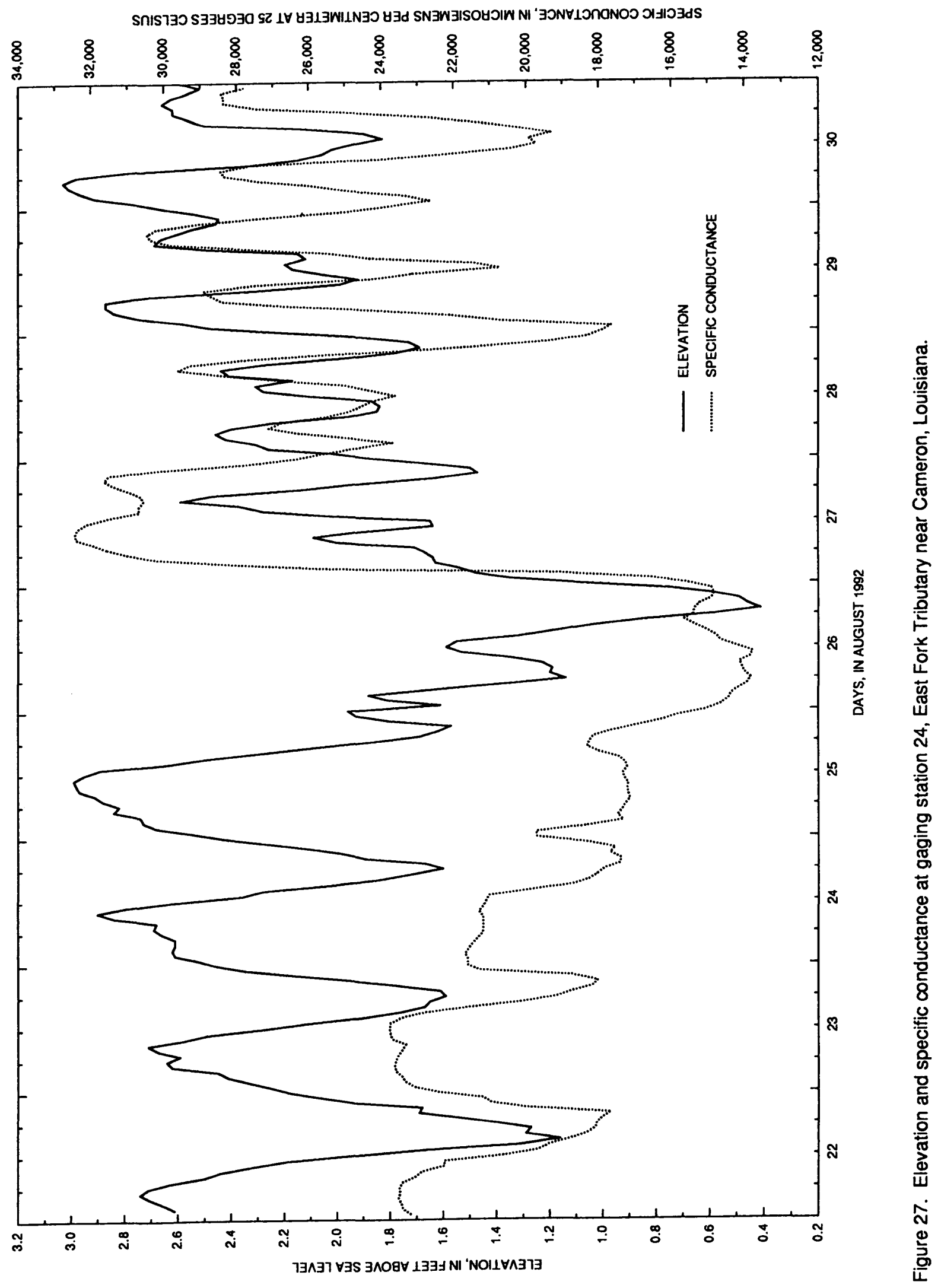




\section{SUMMARY}

On August 26, 1992, at approximately 3:30 a.m., Hurricane Andrew made landfall at Point Chevreuil, La. The hurricane produced a storm tide that affected much of the Louisiana coast, including many coastal waterways and lakes hydraulically connected to the coast. High-water marks resulting from the storm tide on August 25-27, 1992, were located, documented, and surveyed in coastal areas of southeastern and south-central Louisiana. Storm-tide data from 69 high-water marks and 76 gaging stations are presented in tabular form and plotted on twelve $30 \times 60$-minute quadrangle maps as a series of plates. Time-series data from the 24 of the 76 gaging stations are presented as hydrographs.

The counter-clock-wise motion of the hurricane winds pushed water landward in areas east of landfall. From the Mississippi State line to Grand Isle, La., the elevation of the storm tide along the Louisiana coast, generally ranged from 3 to 5 feet above sea level. From Grand Isle to Point Chevreuil, La., the elevation of the storm tide along the coast generally ranged from 4 to 9 feet above sea level. Maximum storm-tide elevations recorded were 9.3 feet above sea level near Cocodrie, La., and 8.2 feet above sea level near landfall at Point Chevreuil, La. West of landfall, the winds pushed the water southward, producing a negative storm tide in areas along the coast to the Texas State line. From landfall to the Texas State line, the negative storm tide generally ranged from 0.5 to 3 feet below sea level. The lowest measurement, 3.3 feet below sea level, was recorded by a gage located at Cypremort Point, La., about 10 miles west of landfall. Other approximate storm-tide elevations (in feet above sea level) along the Louisiana coast were as follows: Lake Pontchartrain, 4; Breton Sound, 5; Barataria Bay, 4; Grand Isle, 4; Terrebonne Bay, 9; Atchafalaya Bay, 8; East Cote Blanche Bay, 8; Vermilion Bay, -3; and Calcasieu Pass, -1.

\section{REFERENCES}

Andel, T.H. van, and Curray, J.R., 1960, Regional aspects of modern sedimentation in northern Gulf of Mexico and similar basins, and paleogeographic significance, in Shepard, F.P., and others, eds., Recent sediments, northwest Gulf of Mexico, 1951-1958: Tulsa, Ok., American Association of Petroleum Geologists, p. 359.

Arcement, G.J., Dantin, L.J., Garrison, C.R., and Lovelace, W.M., 1991, Water resources data Louisiana, water year 1990: U.S. Geological Survey Water-Data Report LA-90-1, 419 p.

National Oceanic and Atmospheric Administration, 1992, Special climate summary, Hurricane Andrew: Columbia, S.C., National Oceanic and Atmospheric Administration, Southeast Regional Climate Center, 7 p.

Rappaport, Edward, 1992, Preliminary report, Hurricane Andrew, 16-28 August 1992: Coral Gables, Fla., National Oceanic and Atmospheric Administration, National Weather Service, National Hurricane Center, $28 \mathrm{p}$.

Shuck-Kolben, R.E., 1990, Storm-tide elevations produced by Hurricane Hugo along the South Carolina coast, September 21-22, 1989: U.S. Geological Survey Open-File Report 90-386, $45 \mathrm{p}$. 



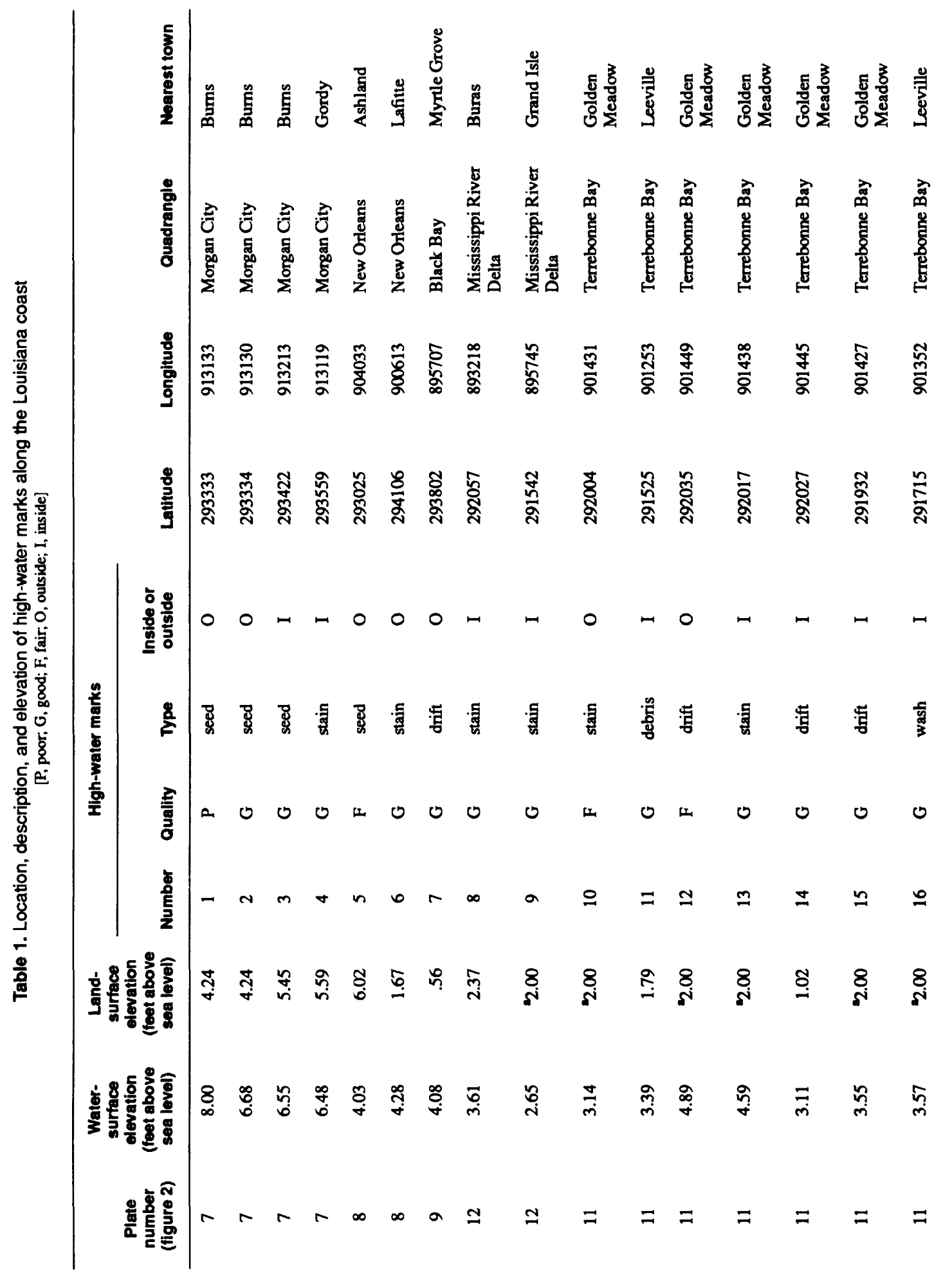




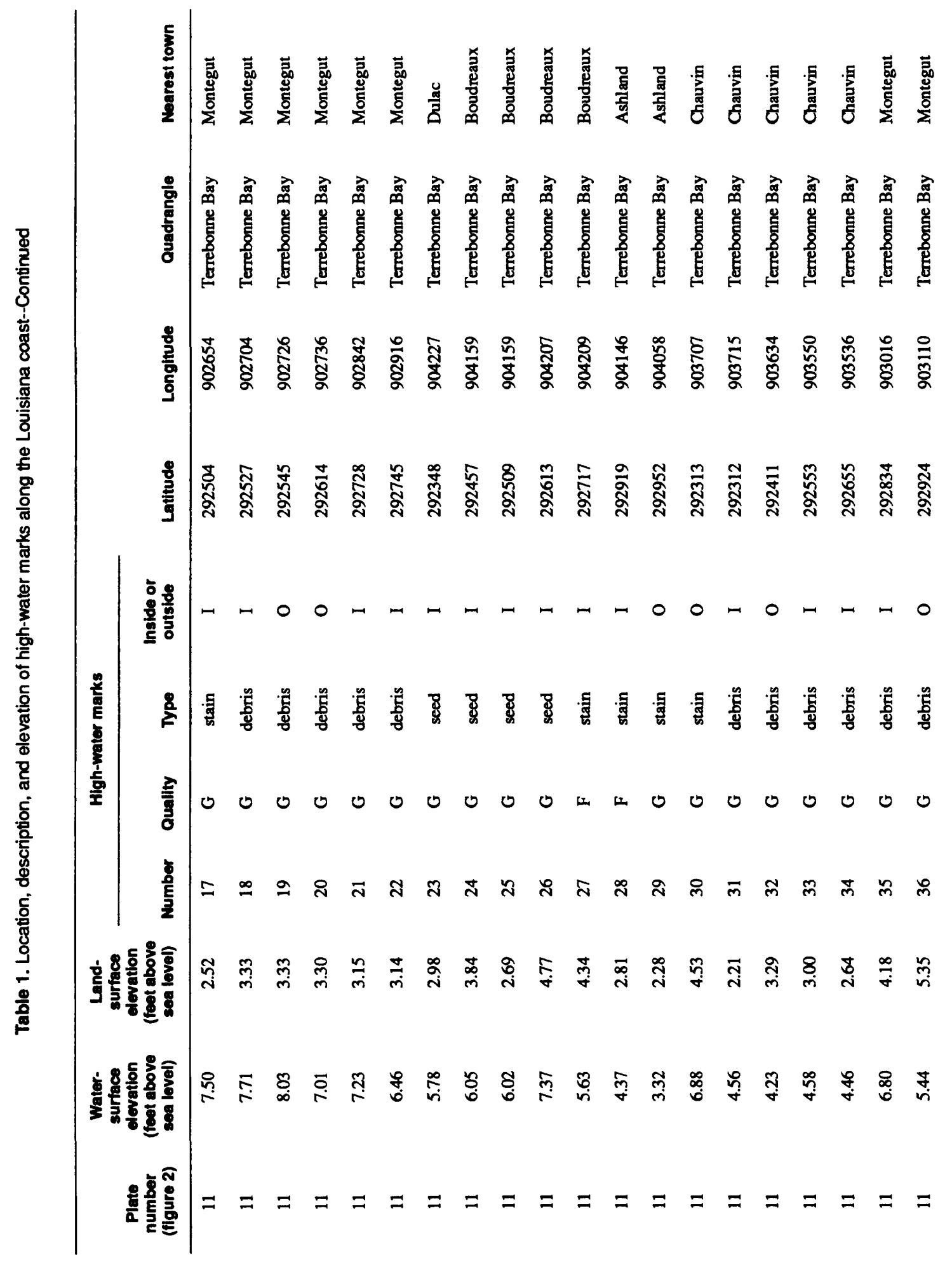




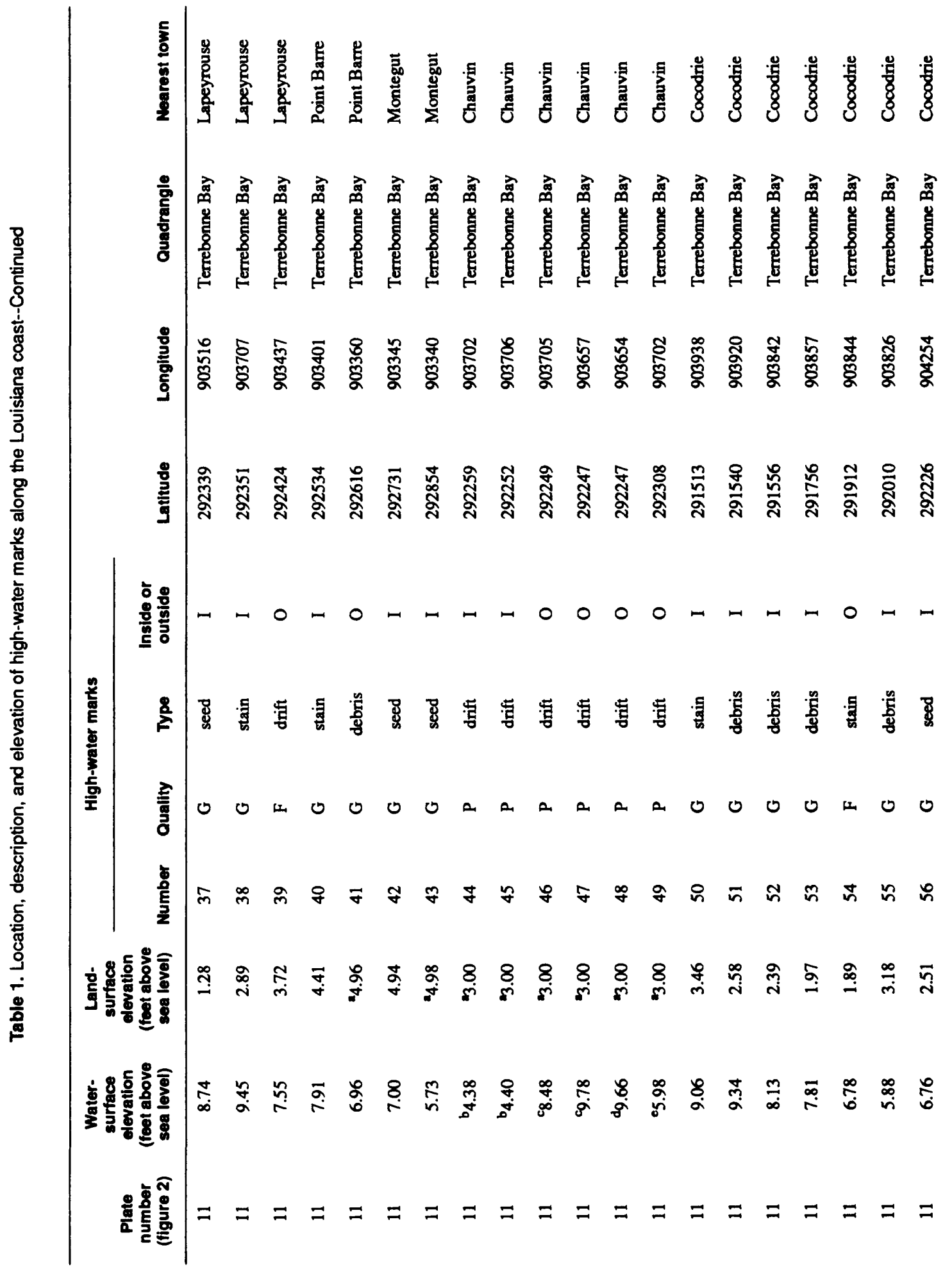




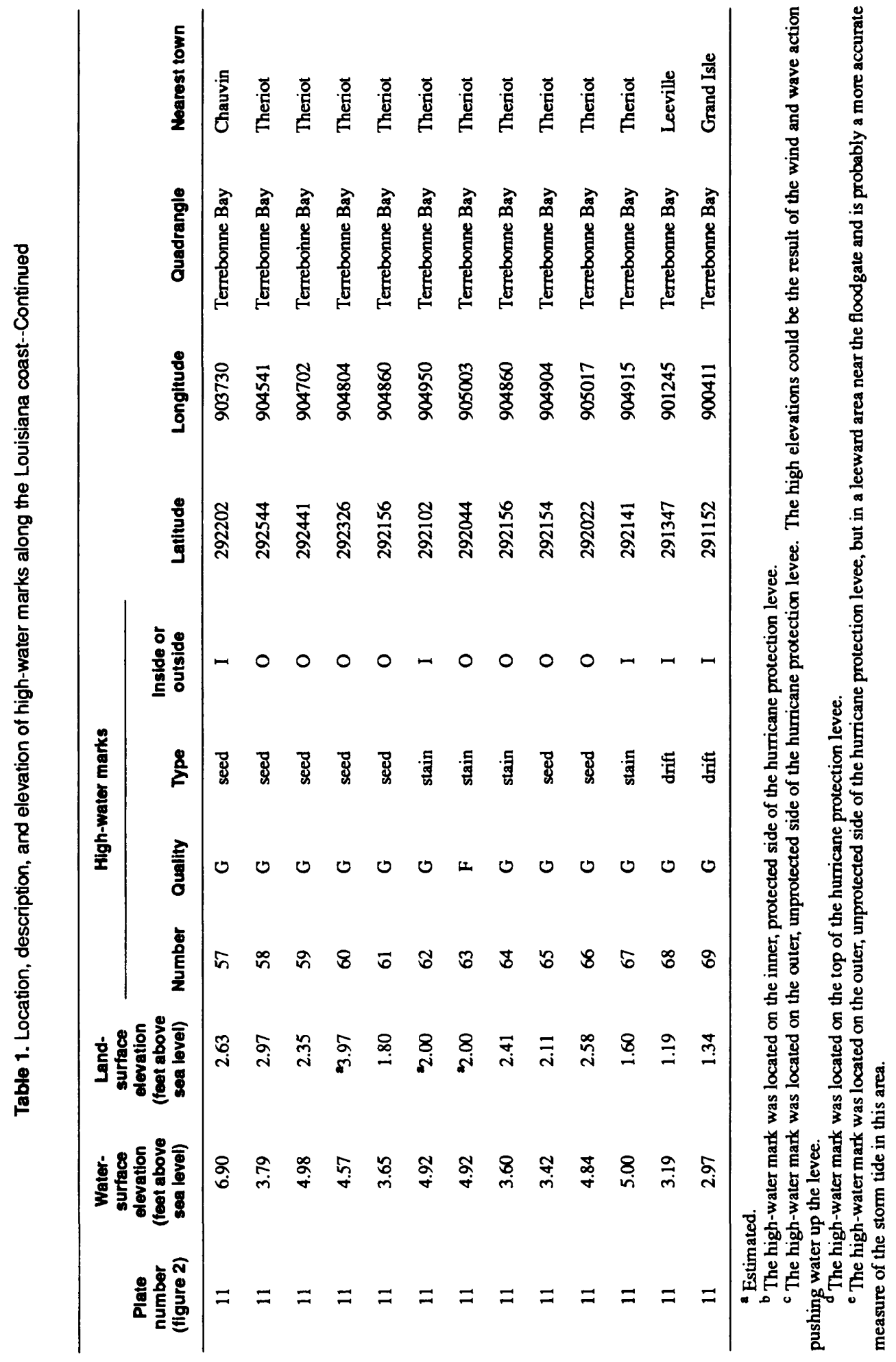




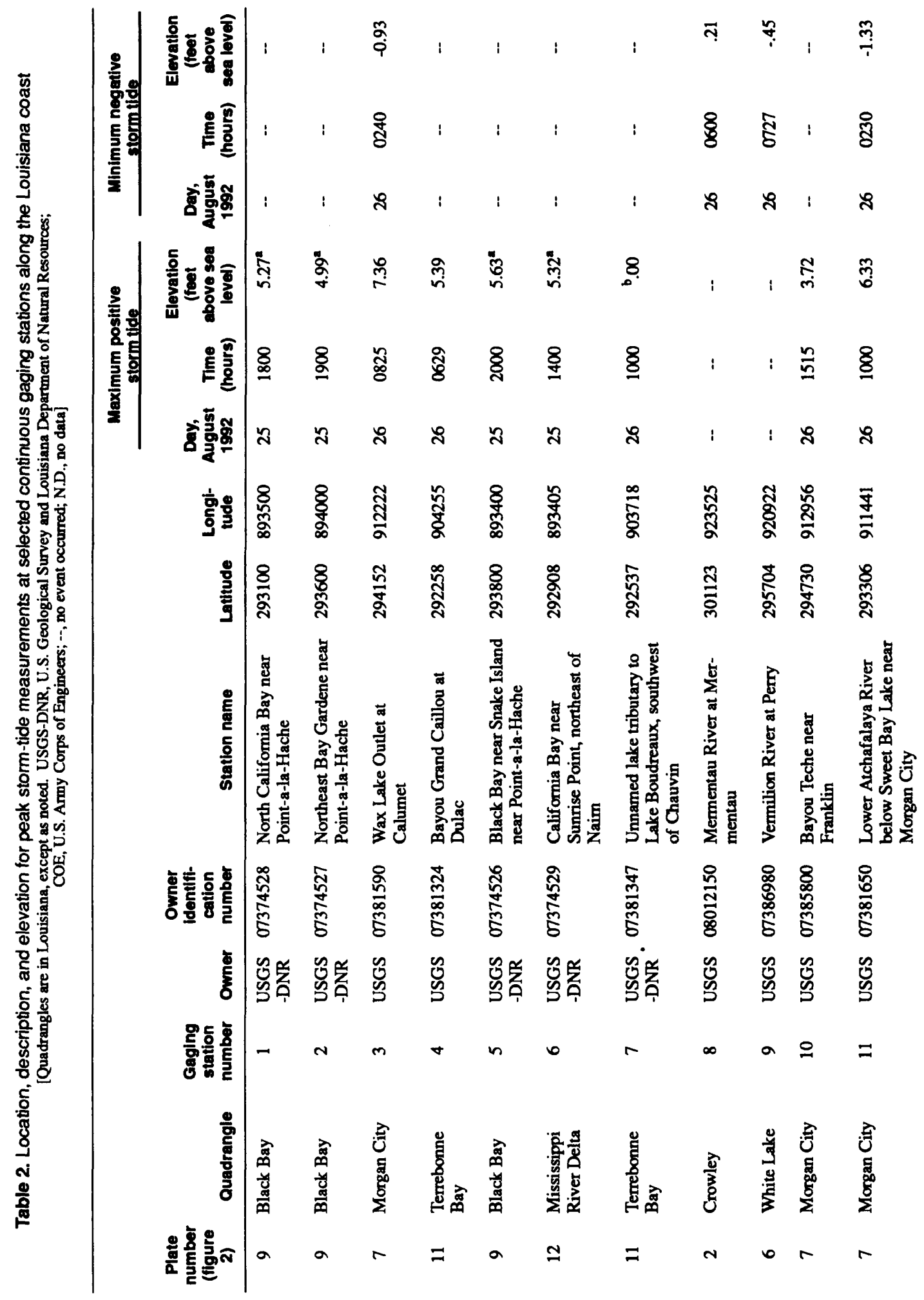




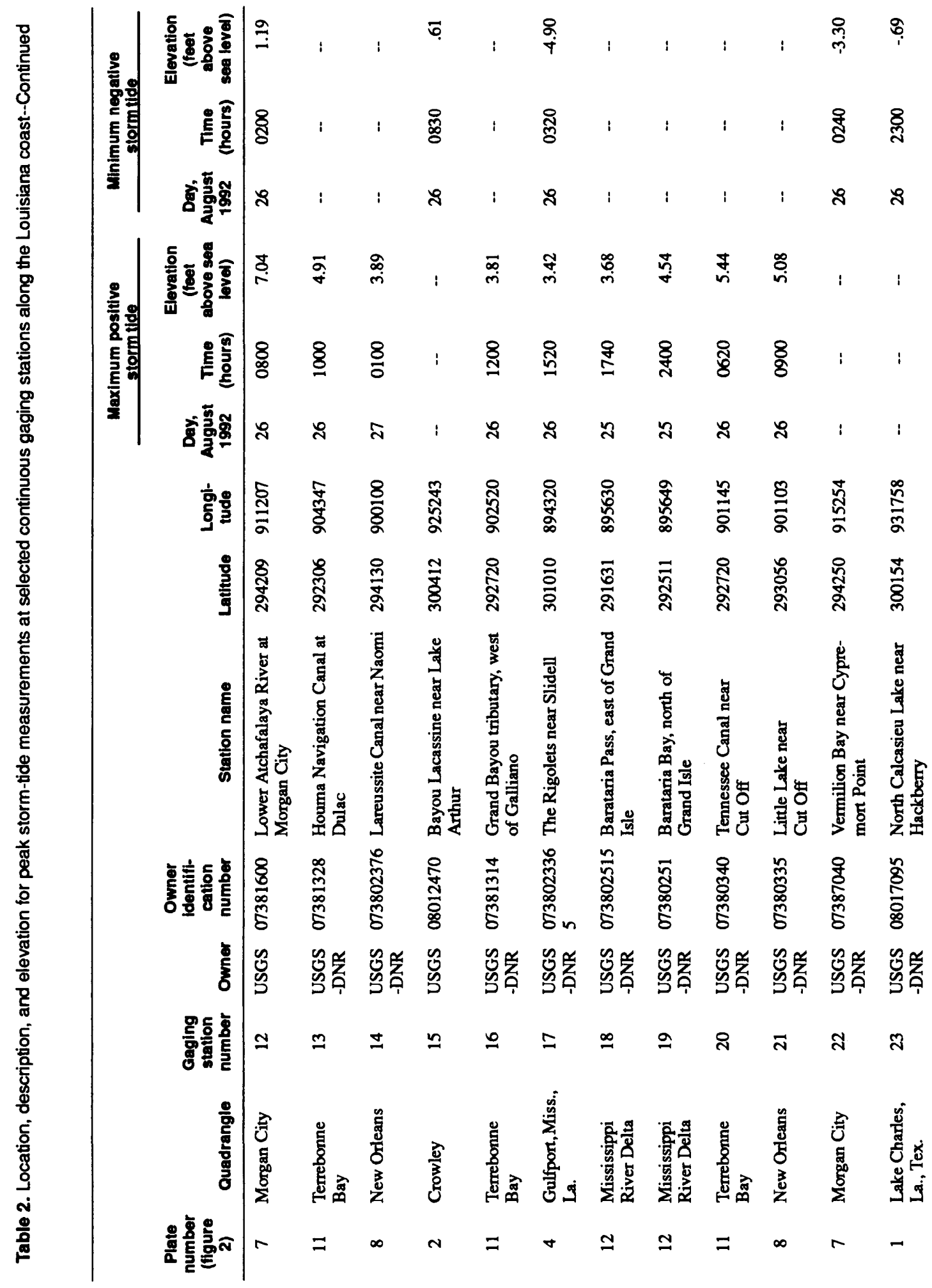




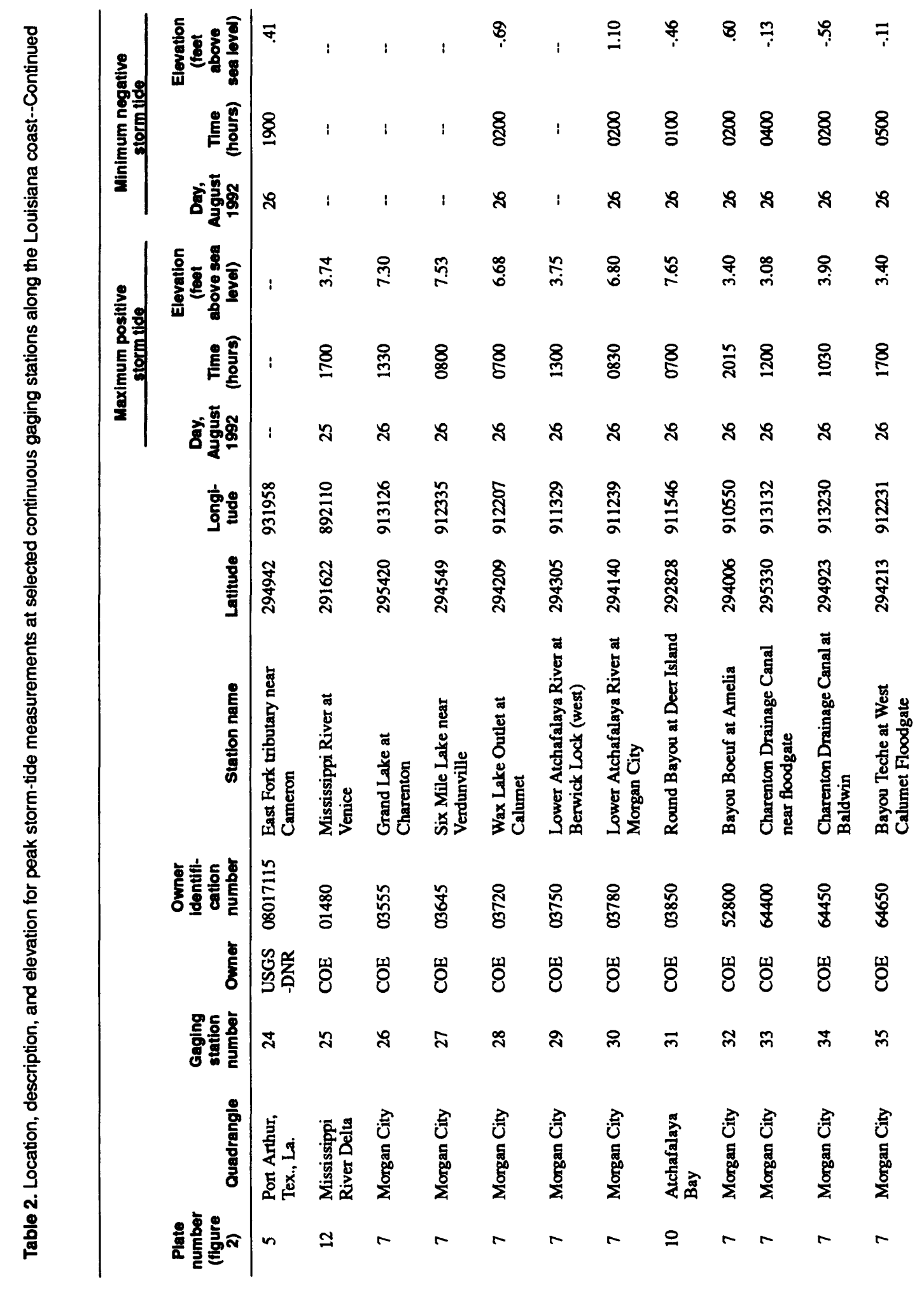




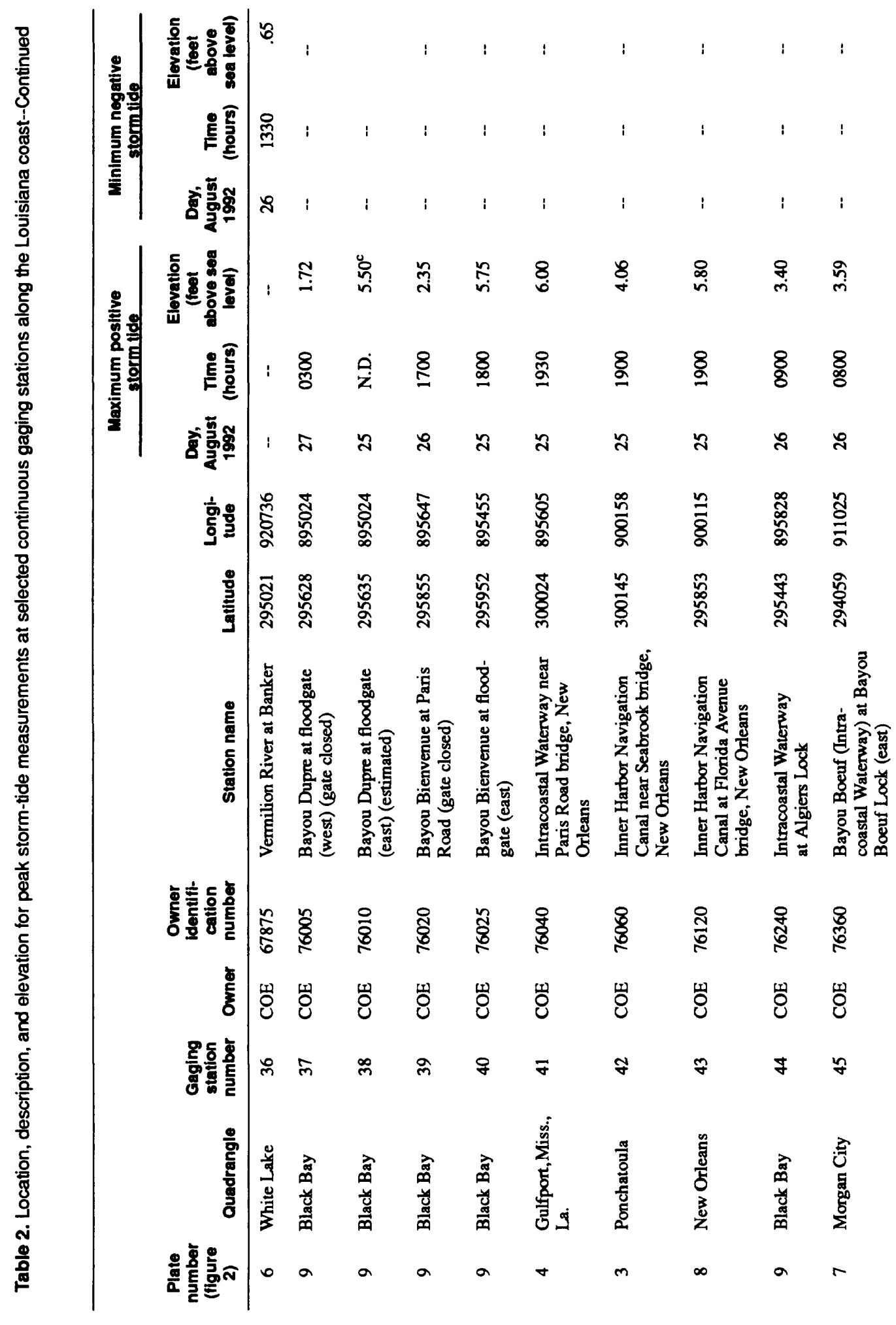




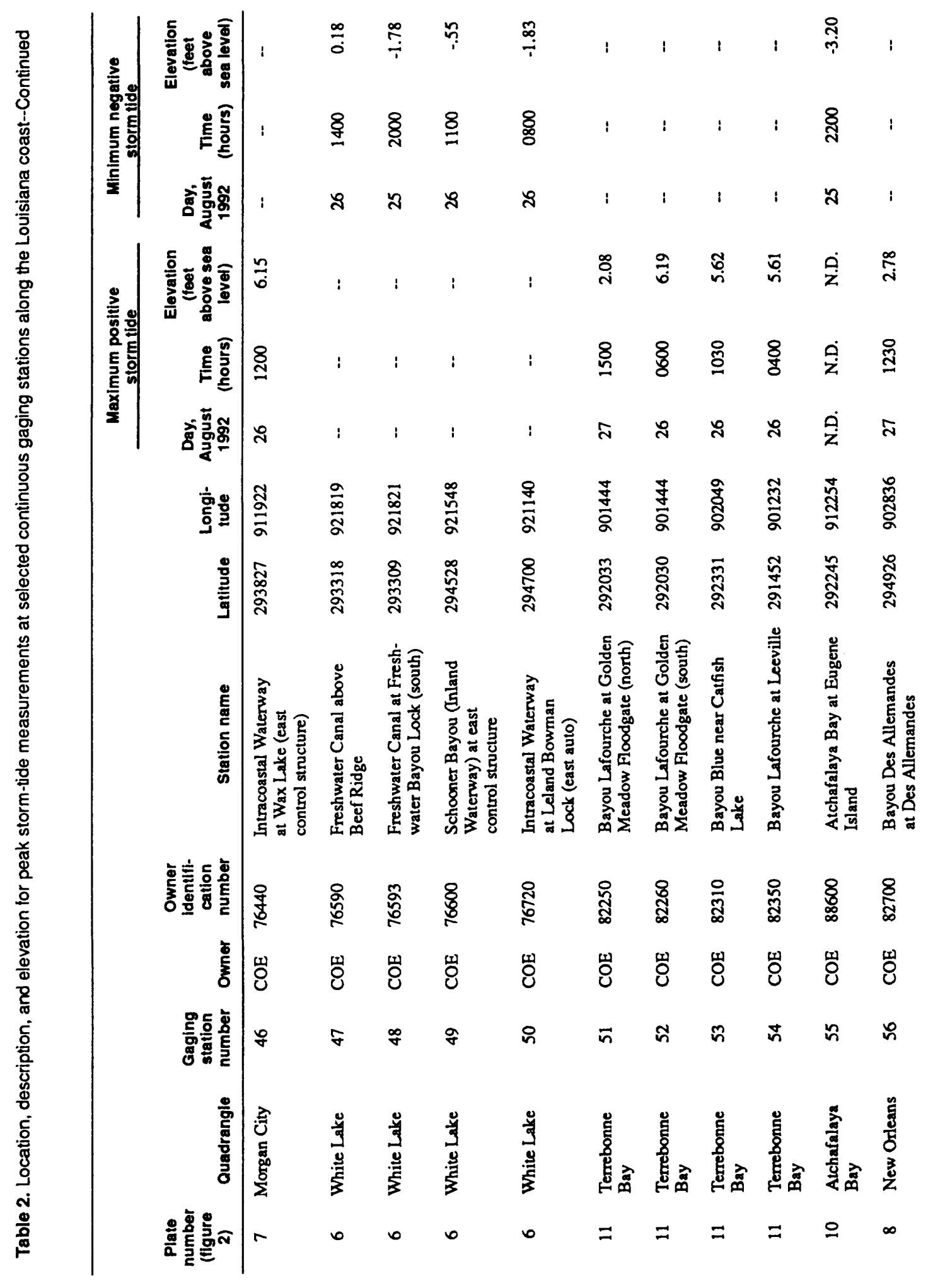




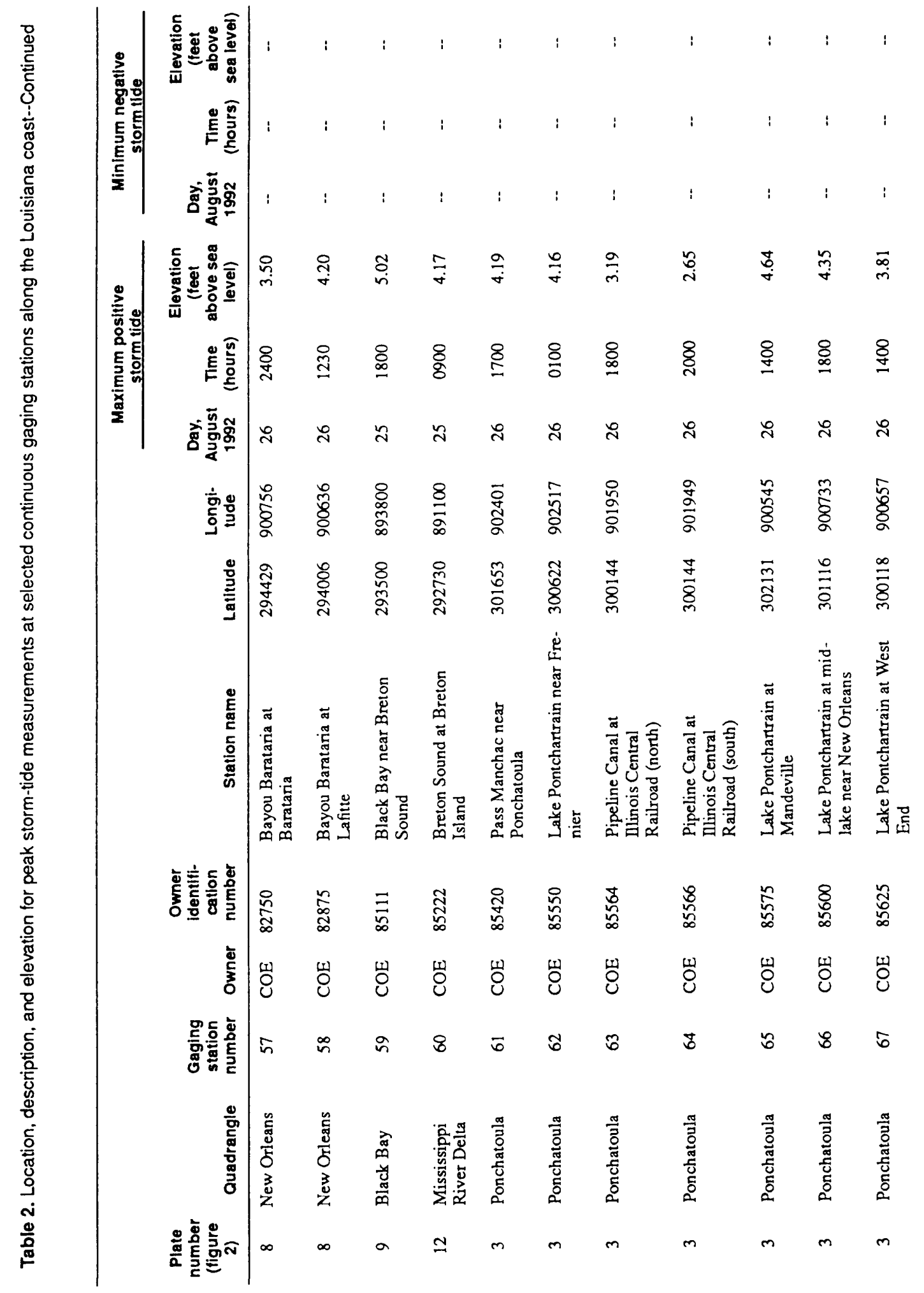




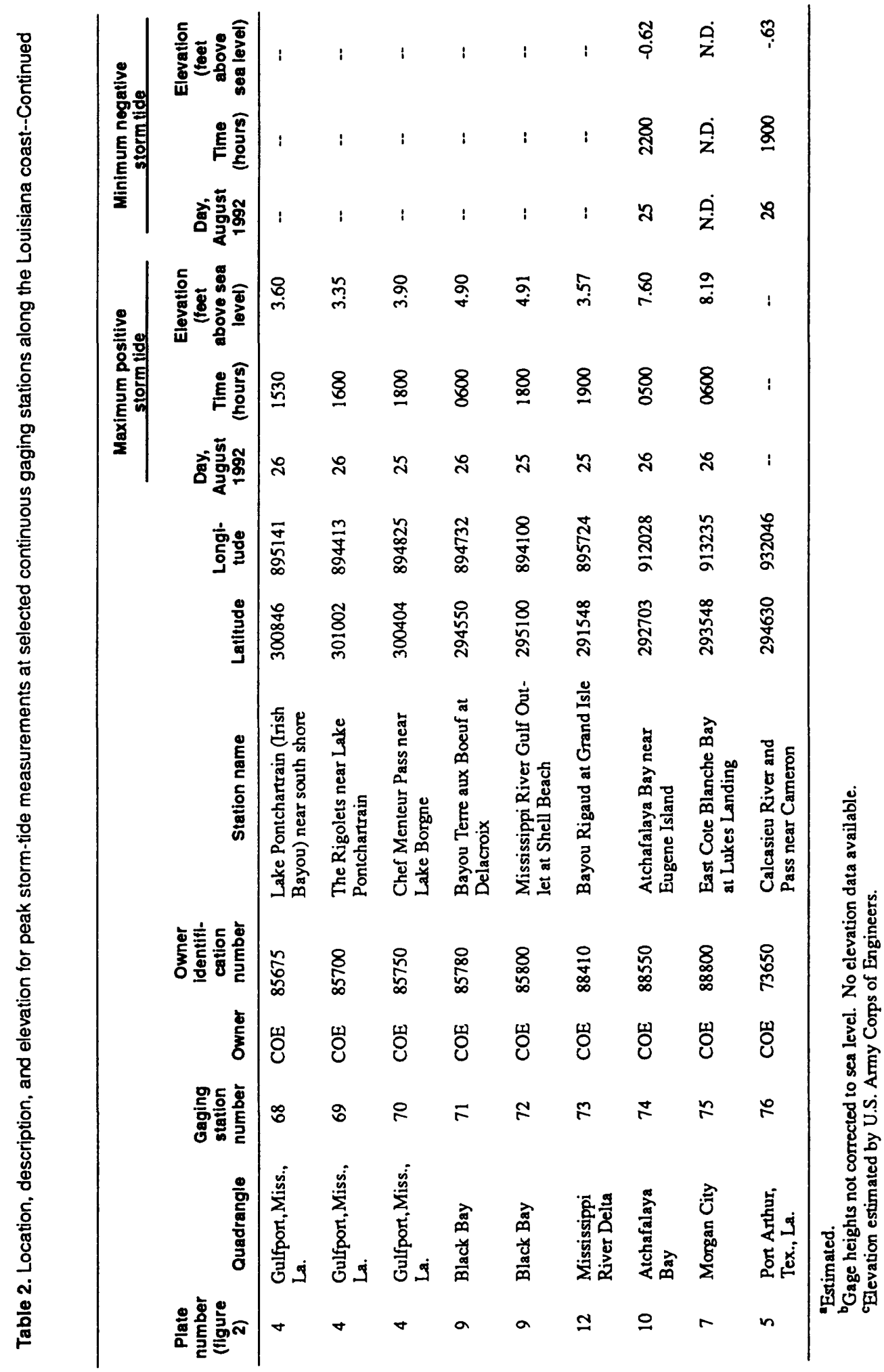

